\title{
Indigeneity, Capitalism, and the Management of Dispossession
}

\author{
by Tania Murray Li
}

\begin{abstract}
Focusing mainly on Asia, this article tracks a link between the collective, inalienable land-tenure regimes currently associated with indigeneity and attempts to prevent piecemeal dispossession of small-scale farmers through land sale and debt. Collective landholding is sometimes imposed by local groups on their own members as they act to defend their livelihoods and communities. More often, however, it has been imposed from outside, first by paternalistic officials of the colonial period and now by a new set of experts and advocates who assume responsibility for deciding who should and who should not be exposed to the risks and opportunities of market engagement. From the perspective of their proponents, however, attempts to institutionalize collective landholdings are not impositions at all. They simply confirm a culturally distinct formation naturally present among "tribal" or "indigenous" people. Yet rural populations have repeatedly failed to conform to the assumptions embedded in schemes designed for their protection. They cross social and spatial boundaries. Some demand recognition of individualized land rights as they respond to market opportunities. Others are unable to escape the extractive relations that visions of cultural alterity and harmonious collectivity too often overlook. Meanwhile, dispossessory processes roll on unrecognized or unobserved.
\end{abstract}

The key words in my title-indigeneity, capitalism, dispossession-are frequently brought together by scholars and activists seeking to expose and contest the devastating threat to indigenous peoples' lives and livelihoods posed by large-scale enclosures of land for dams, mines, logging, or plantations. Capitalism appears in these processes of dispossession as an external force against which indigenous people and their allies stand united. While fully recognizing the importance of this stream of scholarly work and activism and the serious nature of the threats it addresses, my goal in this article is to highlight a different set of relations between indigeneity, capitalism, and dispossession, a set centered on the piecemeal dispossession of small-scale farmers from their land as they are caught up in capitalist processes and the formulation of a concept of indigeneity as a defensive response.

Indigeneity is a mobile term that has been articulated in relation to a range of positions and struggles (Barnes, Gray, and Kingsbury 1995; de la Cadena and Starn 2007; Li 2000). Nevertheless, an important feature of indigeneity in most definitions is the permanent attachment of a group of people to a fixed area of land in a way that marks them as culturally distinct. If we focus for a moment on livelihood practices,

Tania Murray Li is Professor and Canada Research Chair in the Department of Anthropology at the University of Toronto (19 Russell Street, Toronto, Ontario M5S 2S2, Canada [tania.li@utoronto.ca]). This paper was submitted 22 II 08 and accepted 21 III 09. the rationale for collective attachment to land is not always clear. While collective landholding is a built-in feature of production systems such as pastoralism and hunting and gathering, it makes less sense to treat collective landholding among farmers as a natural given. Rather, we might expect that an emphasis on collective tenure over agricultural land would arise only at the point when land becomes scarce, a land market is emerging, and alienation becomes a real possibility. ${ }^{1}$ When this moment comes, groups of farmers may devise their own restrictions on land alienation to stem the threat to their livelihoods and communities, or they may find themselves subject to protective property regimes imposed by authorities and experts who assume responsibility for managing populations, the task Foucault labeled "government."

A classic example of efforts at protection devised from below is the "closed corporate peasant community" of Mesoamerica described by Eric Wolf (1957), with its well-institutionalized system to keep market pressures at bay by drawing tight social boundaries, forbidding the sale of land to "out-

1. See Roseberry and O'Brien (1991) for a critique of evolutionary schemes that situate family and community as the starting points from which history begins. Netting (1993) argues that communal management of forest and pasture tends to coemerge with individualized tenure of farmland and for the same reason: it is only as land and other resources become scarce that anyone tries to regulate access to them.

2. For an extended discussion of my use of the notion of "government" - which I draw from Foucault (1991) — and associated concepts of trusteeship, development, and improvement, see $\mathrm{Li}(2007 b)$. 
siders," enforcing "moral” economies, scorning lavish consumption, and insisting on norms that "share" poverty and restrict accumulation. Significantly, Wolf argued that these tightly bound communities did not precede agrarian capitalism but coemerged with it as farmers recognized the risk of submitting the reproduction of life to market forces alone. The rules, he noted, were culturally elaborated precisely because they were often breached, and they were vulnerable to collapse as market pressures intensified (see Boomgaard 1991 for a review of Wolf's application of the concept of a closed corporate community to Java). Less institutionalized but effective nonetheless, the refusal of Egyptian villagers to make their complex landholding system legible to outsiders through titling can be seen as another example of protection emerging from below: titling would make land easier for the government to tax and easier for outsiders to purchase (Mitchell 2002).

Top-down interventions to protect agrarian populations from dispossession have sometimes confirmed and consolidated popular practices designed for self-protection or have responded to popular demand. Just as often, however, they have imposed forms of protection that farmers do not want or might want but cannot sustain. Rather than a unified multiclass "countermovement" opposing the commodification of land in the name of life, as envisaged by Karl Polanyi (1944), the ground I want to explore in the pages to follow is the complex encounter between groups of farmers and the experts who seek to govern their conduct. As I will show, neither side pulls in a single direction. From the colonial period to the present, farmers and would-be governors have been involved in promoting commodifications and in efforts to prevent commodification, sometimes in coordination but often at loggerheads.

Whether the impetus for protection arises from farmers or from outside experts and authorities, the attribution of cultural difference, emphasizing the unique vulnerability and the special virtue of the group to be protected and their intrinsic attachment to their land, is a central feature of the attempts to manage dispossession that I will describe in this article. These attempts work by imagining collective landholding to be the natural state that protection serves merely to consolidate or perhaps to restore. Hence, they routinely misrecognize or underestimate the forces in relation to which collectivities are constituted and through which they are-just as routinely-undermined. Although capitalism is not the only force at work in indigenous formations, I argue that it has played a more critical role than has been recognized thus far, a finding with significant implications for how we might imagine countering dispossession now and in the future.

For the purpose of this article, which is already rather broad in its scope, I focus on Asia and Africa, where officials in the colonial period explicitly articulated the risks of agrarian capitalism and the virtues of collective tenure as a tool to protect selected groups of people from the risks of market exposure and where these virtues are again being discussed by an ex- panded set of "governors" that includes national and transnational NGOs, development banks, and the United Nations-sponsored rights regime. I begin with an overview of my argument before proceeding to a more detailed analysis of protective intervention in its colonial and contemporary iterations.

\section{Dispossession and the Communal Fix}

As I argued in The Will to Improve ( $\mathrm{Li} 2007 b$ ), the task of officials in late-colonial situations was much more complex than simply acquiring territory or riches for their sovereign or profits for a company. They were expected to exercise a "governmental" rationality that balanced multiple objectives, often in tension with one another and sometimes contradictory. They were to make colonies profitable, find revenue to support the costs of administration, ensure order and stability, and improve the condition of the colonized population. A key arena for the working out of these contradictory mandates was the management of relations between rural populations and agricultural land.

The dilemma over land in colonial Asia and Africa can be roughly summarized as follows. Considerations of profit required that segments of the colonized population be displaced from the land they occupied to make room for plantation agriculture or white settlement. Considerations of revenue suggested stabilizing a peasant population that could be taxed or obliged to pay rent to a landlord state. But displacing populations or subjecting them to excessive rents and taxes threatened order and stability. Further, defining appropriate land rights for the colonized population hinged on the question of how best to improve that population. Should they be subjected to the healthy discipline of market forces by making land into a commodity? Or should they be protected from the dispossessory effects of a land market and set on a different course of improvement better suited to their needs, capacities, or stage of development-in short, their otherness? Anxiety, nostalgia, and moral doubt figured strongly in these debates because colonial officials-like their contemporary counterparts-held different views on whether capitalism was the goal to be achieved or the nightmare to be avoided. Anthropologists played an important role in these debates by describing alternatives to capitalism that could still be found among the colonized population, perhaps intact or perhaps damaged but potentially restored.

A common approach to the land question in the colonial period was to divide the population, separating people who were designated to become fully competent market subjects with individual possession of their land from those who should be protected from the risk of dispossession by cementing their attachment to land on a collective basis. The division was often wrought on a spatial axis. In much of colonial Africa, the axis was urban/rural, as urban people became individualized rights-bearing citizens and rural people became subjects of tribal authorities that managed land on 
behalf of a group (Mamdani 1996). In Asia, the axis was more often vertical, as lowland people became tax- and rent-paying smallholders with individual tenure while upland people were treated as collectivities. These distinctions sometimes coincided with differences in production regime (pastoralism vs. farming, shifting cultivation vs. fixed field agriculture). Often, however, they did not: groups engaged in identical forms of production could find themselves on either side of the tribe/ peasant divide. Initial distinctions in forms of production and landholding, if there were any, were deepened as colonial legal regimes constituted subjects with differential rights to own, use, or transfer land and imposed separate administrative arrangements.

Dividing populations and enclosing bounded groups on limited land offered colonial officials an efficient solution to several problems at once: clearing land for colonial plantations and settlement and enabling efficient taxation, administration, and indirect rule. A further feature of the communal fix, the one I highlight here, was the solution it seemed to offer to the vexing tendency of the colonized to dispossess themselves through land sale or debt. The problem arose among farmers caught in what Henry Bernstein (1994:56) calls the "simple reproduction squeeze," an endemic feature of the capitalist social relations of production and reproduction that have prevailed in agrarian settings everywhere for at least one century, often two, imposing themselves on farmers with varying degrees of intensity. ${ }^{3}$ When taxes and rents are high, when subsistence crops fail, or when the price fetched by cash crops does not match the cost of food and inputs, farmers are compelled to borrow money at high interest or mortgage their property as they enter a downward spiral.

In some contexts, it is efficiency of production that distinguishes the farmers who survive this squeeze from those who end up losing their land (Wood 2002). In much of rural Asia, however, the principal mechanism through which owners of capital have been able to profit from rural peoples' labor and the principal vector of dispossession long before the introduction of high-input agriculture has been debt. Whether the creditor is an outsider or a covillager, interest on preharvest loans in cash or food routinely runs around 30\%-50\%. Jan Breman terms this mode of extraction "rent capitalism" (Breman 1983:55-56, 114; see also Husken 1989; Pincus 1996; White and Wiradi 1989) because owners of capital — which is held in the form of land, money, or stocks of grain-have little incentive to invest in more efficient production, and they do not necessarily need to control all the land directly. Instead, debt makes nominally independent landholders in effect their tenants, disciplined by the need for further loans

3. Chayanov's (1986) theory of peasant underproduction was formulated in a context where market incentives were unusually weak. For illuminating discussions of the mechanisms that compelled peasants in western Europe to intensify production, see Brenner (1985) and Wood (2002). Netting (1993) discusses peasant strategies to preserve autonomy. and the threat of foreclosure. Other scholars call this situation partial or disguised proletarianization. ${ }^{4}$

Colonial authorities of the nineteenth century attempting to govern relations between people and land sometimes encouraged the spiral into landlessness in the name of market efficiency. Alternatively, they sought to manage it by calibrating prices, taxes, rents, wages, and interest to adjust the rate at which farmers held on to or lost their land. Similar calibrations were made in England and Scotland ca. 1800 as scholars and officials debated how much dispossession was necessary to produce disciplined labor and how much was too much, raising the cost of labor or worse, producing an undisciplined and threatening mob (Perelman 2000). These calibrations are still being made today as experts debate the merits of agricultural subsidies. Do they protect livelihoods or protect inefficiency and jeopardize poverty-reducing growth (Bernstein 2004; Bryceson 2002; Byres 2004; Kanbur 2001)? Put another way, the conditions governing the socalled free market are always set, and the way they are set is the outcome of struggles among different social forces and attempts to manage them.

In addition to setting the conditions governing markets and rates of extraction, colonial and contemporary regimes have attempted to limit dispossession by intervening directly to shape the conduct of farmers. They use law as a tactic, forbidding the mortgage or sale of land, outlawing usury, or fixing interest rates. They also launch educational campaigns to convince feckless and foolish farmers that they should work harder and avoid debt. But loans, mortgages, and sales are dispersed transactions, often unregistered and easily disguised. The effect of restrictions is seldom to prevent sale but rather to drive it underground, reducing the price of land and increasing the cost of credit (the perverse effects of prohibiting land sale and mortgage are discussed in Alexander and Alexander 1991; Deininger and Binswanger 2001). Governing the conduct of millions of individual farmers is no easy task. Governing the conduct of selected groups by making their landholding collective and inalienable is an attempt to address this problem: a farmer subject to this kind of tenure regime cannot sell up and cannot be dispossessed.

In the colonial period, as I will show, officials who insisted that the proper form of landholding among the rural population (as a whole, or particular subsets of the population) was collective and inalienable hoped to bind people permanently in place. A racialized paternalism provided these officials with a ready rationale: groups the authorities deemed to be culturally unsuited or otherwise unfit to become full market subjects should be protected from market risk. Although officials recognized that members of the groups they were concerned with protecting often had the right to use

4. For useful reviews of debates on this topic, see Bernstein (2004) and Akram-Lodhi and Kay (2009). See also Ben White's classic essay (1989) arguing for careful attention to the diverse mechanisms of differentiation and surplus extraction in agrarian settings. 
agricultural land individually, they assumed that use rights were equitably shared. Further, they insisted that members of these groups did not have a culturally affirmed right to transfer land across the boundaries-defined as a village, clan, tribe, or tribal district, the units varying by context—of their group. However, to the officials' dismay, rural populations repeatedly failed to conform to the assumptions embedded in the administrative regimes designed for their protection. Imputed differences between peasants and tribes did not hold. People the authorities defined as tribes crossed social or geographic boundaries, demanded state recognition of individualized land rights, and evaded restrictions on mortgage and sale. Some did so out of desire, as they responded to market opportunities and took risks their would-be protectors deemed inappropriate. Often, however, they were unable to conform to expectations because they were caught up in mechanisms of dispossession that colonial authorities routinely overlooked or underestimated: the debt was there, the price fetched by their commodities was thus, the cost of inputs exceeded the returns, their land was too small, they could not make ends meet.

In the contemporary period, as I will explain, a new set of experts and advocates has emerged stressing the virtue of collective, inalienable landholding as a means to protect rural people from dispossession. The World Bank, for example, which continues to promote the commodification of land through titling to transform inefficient smallholders into proper capitalists, has come to recognize that there are good, pragmatic reasons to keep some land outside the market because of its social-insurance function. The World Bank now looks around for indigenous people securely ensconced in collectively held territories who can benefit from market opportunity but not bear the risk of market competition because they cannot be dispossessed. Advocates concerned about forest conservation also seek to fix indigenous people in place, not to support their farming ventures but to limit them in favor of "community-based forest management." Their interventions, like those of other advocates and experts wearing the mantle of "government," repeat the colonial tendency to overestimate the bonds of community and underestimate or misread the mechanisms through which dispossession occurs. Further, their efforts raise the thorny problem of paternalism. Who decides when people should or should not be exposed to the risks and benefits of market engagement? This problem was less pressing in the colonial period, when the assumed racial hierarchy and the prerogatives of rule made the issue of paternalism mute, but it arises sharply today as concepts of cultural relativism and respect for difference are widely promoted. It is less clear why one group should decide what is good for another. I take up these contemporary dynamics after exploring the colonial land regimes through which collective, inalienable tenures became entrenched.

\section{Managing Dispossession in Colonial Situations}

\section{British India}

I begin with British India, where the concern to generate revenue dominated the land question. There was a century of debate (1840-1940) on how best to achieve this: by treating village communities as "little republics," cohesive social and territorial units that should be bounded, stabilized, taxed, and preserved; or by encouraging a form of agrarian capitalism in which "improving" landlords or entrepreneurial farmers would increase production and the taxable base. As Clive Dewey explains, the stance officials took toward village communities was intimately linked to their stance on the costs and benefits of capitalism, which they viewed as incompatible with Indian village life. If Indian villagers were granted the freedom to alienate land, if moneylenders could foreclose in the event of unpaid debts, or if village officials could foreclose to collect on tax arrears, the result would be the breakdown of village cohesion and the displacement of paupers from the land. Some officials saw this as a necessary step in the path to progress and efficiency. For several reasons, others saw it as a social disaster: (1) there would be a loss of the virtue of communal life, setting India on the course to rural dispossession that had already wreaked havoc in Europe; (2) there would be a travesty of the evolutionary order, because Indians, as a primitive race, were still at the stage of communalism and were unprepared for private property; or (3) there would be a threat to the stable hierarchy that underwrote British rule (Dewey 1972; Dirks 1992).

Had the arguments for sustaining communities and, more importantly, for treating land as the collective, inalienable property of village republics won the day, the entire population of rural India might have been fixed in place. Instead, the argument that land was or should be held collectively by villagers was overwhelmed by the sad, dull facts of village life. Ethnographic research by scholar officials began to show that property was not actually held by communities, it was held by individuals or families who vigorously asserted their right to control it; further, debt, mortgage, and the sale of land were pervasive in the Indian countryside (Dewey 1972). Collective village landholding, if it had ever existed, could not be restored.

Even as private individual property in land became de facto the dominant form in India, the British passed numerous regulations that attempted to restrict the transfer of land from cultivators to moneylenders, a group unfit to be landholders in British eyes. The effort to limit or, indeed, to rescind land transactions began early in the nineteenth century, and regulations to this end were imposed in much of India. They were most elaborate, however, for a category of people singled out for special protection: the population of the hills, people the British labeled tribes, who were renamed adivasi on independence and who are currently recognized as indigenous 
people by the United Nations (UN). The government of India rejects the category "indigenous," but it continues to recognize the colonial category "tribe." As of 2000, India's officially recognized "tribal" population numbered about 68 million, $8 \%$ of India's total (see Bijoy 2003; Colchester, n.d.; Karlsson 2003).

How did India's distinct tribal population come to be? Historian Prathama Banerjee argues that "no one existed as an authentic 'primitive,' until s/he was colonized, bounded and deprived of practical political relations to 'mainstream' society and to the world" (Banerjee 2000:425). She traces an early example of this process in colonial Bengal in the 1830s, where the British installed a migratory group called the Santals in the Rajmahal Hills, displacing the previous occupants, the Paharias, whom the British judged unsuitable for the tribal position as they envisaged it (Banerjee 2000:430). Having installed the Santals in the designated place, the British set about separating them from the general population. By 1853 the British had built a physical fence, complete with police posts, to enclose the Santal population, and they proceeded to evict Hindus/Bengalis living in their midst. They also restricted market transactions in Santal areas, forbidding all trade except in supervised marketplaces, because they were convinced the Santals could not handle money-witness their chronic propensity to fall into debt.

The evolutionary thinking that positioned tribal people as the most primitive, hence the least fit for capitalism, was joined by a colonial raciology that identified India's "tribes" not in their ethnolinguistic specificity, as components of a very diverse Indian population, but as a generic category defined in temporal terms. The tribal population, colonial anthropologists argued, was the original population of India that had been conquered, displaced, and maltreated by HinduAryan invaders from whom the British should now protect them (Pels 1999). As anthropologists further elaborated their evolutionary schemes and linked evolutionary stages with modes of subsistence, officials seized on small differences between groups and magnified them, erasing the awkward fact that "the so-called tribes shared more cultural, social and economic practices with their caste neighbours in the region than with the other 'tribes' all over India with whom British officials clubbed them" (Skaria 1997:732). Officials then entrenched these presumed differences by establishing special administrative arrangements that confined "tribal" populations to tribal districts in which the laws applied to the general population were suspended and rule was conducted by special agents, commissioners, and missionaries empowered to exercise an especially paternalistic form of authority backed by notions of "customary" law (Ghosh 2006). Officials devised a raft of legal and regulatory measures to prevent the transfer of land from tribal to nontribal hands. While their effect on dispossession was modest, these regulations further fixed the concept of tribal people as a bounded group, forever in place. The regulations also responded to pressure from below, as "tribal" groups launched rebellions and uprisings, stimulated by their grievances against nontribal landlords and moneylenders (Banerjee 2000; Bijoy 2003; Colchester, n.d.; Damodaran 2002; Ghosh 2006).

At independence, the Indian Congress Party adopted a policy of assimilation for tribal populations, rejecting the isolationist approach of the British on the grounds that it attempted to suspend change, preserving tribal people like specimens in a zoo (Corbridge 1988; Skaria 1997). Assimilation policies notwithstanding, land regulations in the protective colonial mold are still being passed in India. In Orissa, an amended regulation in 2003 ruled that "no tribal can transfer his land to a nontribal or even to another tribal if he possesses less than two acres of irrigated land or less than five acres of un-irrigated land" (Upadhyay 2003:1). Note that the regulation sets a lower limit to landholding. It does not target the greedy accumulator but the farmer who might foolishly dispossess himself. Further, in response to advocacy highlighting the role of large-scale state-sponsored enclosures in tribal dispossession, India's Supreme Court ruled in 1998 that evicted tribals must be given land in compensation. The protective move retained a paternalistic flavor, as the court concurred with advocates for tribal people who argued that land is the only appropriate form of compensation for this groupideally, land they cannot sell-because they are still incompetent to handle cash (Ghosh 2006:510-513).

Postindependence approaches to governing the relation between "tribal" populations and land in India maintain what Stuart Corbridge (1988) calls "the ideology of tribal economy and society," initiated in the colonial period and still intact, according to which bounded tribes occupy bounded space, equitably share access to land and forest, and stand united in their commitment to a communal and subsistence-oriented way of life. Contra this ideology, critics argue that there is no evidence for the existence of tribes in modern India based on any of the standard criteria used to define tribes in other contexts (autonomous political organization, isolation from national society, or sharp differences in language, religion, or mode of livelihood from the surrounding "peasant" population). The only clear distinction between the scheduled tribes and others is the schedule itself-the list devised in the colonial period, appended to the constitution, and periodically revised as groups struggle to be added to or subtracted from it, as their political and economic agendas dictate (Beteille 1998; Corbridge 1988). Legal restrictions on land sales notwithstanding, piecemeal dispossession continues. In the "tribal" part of South Bihar now known as Jharkhand, the degree of inequality in landholding among tribals in 1971 was almost identical to that among their nontribal neighbors as money lending, debt, and accumulation occurred both within and across these populations (Corbridge 1988:34-35).

\section{British Rule in Southeast Asia}

In Southeast Asia, as in India, colonial authorities worried over the proper form of land tenure for the native population. 
In the long-settled villages of the rice-producing lowlands, landlessness, sharecropping, rent, debt, and taxation based on landholding were already common early in the nineteenth century (Elson 1997:123). In British Burma early in the twentieth century, rapid and acute land concentration in the Burma delta led the British to offer peasants secure title and exemption from taxes if they promised not to mortgage their land-to little avail (Elson 1997:134, 137). In the hilly hinterlands of Southeast Asia, population was relatively sparse, forests were extensive, and mobility was common. This situation presented the British and other colonial powers in the region with a different dilemma, as they were repeatedly surprised, and horrified, by the willingness of farmers in these zones to take up production of "boom" commodities such as rubber, coffee, and coconut and their rapid slide into debt resulting in the mortgage and sale of land (Elson 1997: 97-103, 105-115, 196-198). British solutions to this "problem" illustrate their assumptions about who should—and who should not-be exposed to market risks.

In Malaya, British design for the colony was to develop plantation agriculture on vacant land using indentured labor imported from India and to leave the native Malay population untouched so that they could pursue the peasant-style, ricebased subsistence agriculture for which the British thought they were well suited. The Malays, however, had other plans. First, they readily took up plantation crops such as rubber and coconut on their smallholdings, competed with plantations, and sometimes neglected food production or abandoned it altogether (Elson 1997:100-101). Second, they failed to stay in place. Paul Kratoska (1985) describes the alarm of British officials at the odd behaviour of these "peripatetic peasants," people who, contra British expectations, showed no interest in the land titles the British offered them at very low cost, readily sold or mortgaged their land to raise some capital or pay off debts, and moved at will to new locations where they leased, borrowed, or cleared land on the forest frontier.

While the British expected Malaya's immigrant Chinese population to be entrepreneurial, they expected the Malays to be committed to rice production and a stable village life. Attempting to make sense of Malay behaviour, the British made a distinction between inherited rice land, to which they thought Malays would have an emotional attachment, and land under rubber that was just to earn cash. But there was no evidence that Malays made this distinction. It was, Kratoska argues, the British who were sentimental about land and disappointed the Malays were not (1985:41). To protect the Malays from their own feckless behavior, from the Chinese who the British accused of taking advantage, and from European planters seeking to expand their estates, the British decided to reserve "customary land" for exclusive Malay use. This land could be sold, but only among Malays (see Elson 1997:137; Kratoska 1985:35-36; Tsing 2003:157). The preamble to the 1912 draft of the Malay Reservation Enactment conveys the tenor of the argument.
For some time past the Rulers of the Federated Malay States and their Advisers have been caused grave anxiety by the fact that their Malay subjects deluded by visions of present but transitory wealth have been divesting themselves of their homestead and family lands to any one willing to pay in cash for them. Blinded by the radiance and inducements offered, entranced by the visions of lethean pleasures conjured up they fail to realize that for those elusory [sic] pleasures they are surrendering and sacrificing the happiness of a life-time. Thus a race of yeoman-peasantry aforetime happy and prosperous ... find too late that they have become homeless wanderers in their own land. The Rulers of the Federated Malay States and their Advisers conclusively feel that unless a better judgment is exercised on their behalf the result will be the extinction of the Malay yeomanpeasantry. (Quoted in Tsing 2003:130-131.)

This is a good example of how categories slide: when the Malays failed to occupy the position of individualized yeoman peasants to which the British had assigned them, they were reassigned to a protected group status in which land was reserved for them collectively. Although Malays vigorously resisted British attempts to restrict their right to mortgage and sell their land, about $60 \%$ of land held by Malays was enclosed in the reservation system by 1930 and more in the next decade (Kratoska 1985:36). Colonial protection notwithstanding, many Malays did become landless, and among those who remained on the land, class differentiation proceeded apace. The protections Malays devised for themselves took different forms, such as the claims on patrons to provide livelihood security and the protest tactics described by James Scott (1985), neither of them especially effective.

In Sarawak (now East Malaysia), the Brooke Rajahs who ruled from 1841 to 1941 created the category Native Customary Land (1931) explicitly designed to protect Dayak groups in the hinterland from impoverishing themselves by selling their land to the Chinese. The Land Code of 1958, passed after authority shifted to the British crown, retained the protected status of customary land but permitted individual tenure and land alienation in the "Mixed Zone," where officials deemed the Dayak capable of managing their own affairs (Cramb 2007; Peluso and Vandergeest 2001; similar protective regulations were passed by the British Borneo Company in what is now Sabah; Cleary 1992; Doolittle 2005). This is an example of a shift from a positioning as a member of a protected group to a positioning as competent market subjects based on a concept of cultural adaptation.

Sarawak's colonial-era racialized protective land classification was progressive from one perspective: it was unique in the region for recognizing the legitimacy of shifting cultivation and including forests within the boundaries of the land reserved for Dayak use. ${ }^{5}$ However, from another per-

5. Recognition of forest as an integral part of customary territories is a key demand of the contemporary indigenous rights movement throughout Asia. Even when legally entrenched, rights to customary territories 
spective, it was deeply conservative. It overlooked the dynamism of Dayak land use, especially the extraordinary enthusiasm of Dayak farmers for commercial agriculture. Dayak smallholders commenced rubber production around 1910, some of them employing Chinese workers to plant up to 20 hectares. They later added pepper to their repertoire, and pepper groves continue to supply up to $80 \%$ of Dayak household income in the more remote areas, where relatively high value for weight makes pepper production competitive (Cramb 2007).

Colonial thinking about the incapacity of the Dayak population continues to shape land politics. The current Sarawak government deploys the colonial argument that the native population lacks an interest in commerce and must be protected in order to exclude Dayak smallholders from participating in the oil palm boom that is bringing new riches (and impoverishment) to rural areas. To free up "protected" native reserve land for oil palm development, the government has instituted a legal procedure for converting customary land rights into "shares" in private-sector oil palm ventures in which the corporation takes over from the colonial authority as "trustee" for native welfare (this program is described in Cooke 2002; Cramb 2007). Having designated Dayak people collectively as inappropriate and incapable market subjects, the government actively restricts Dayak smallholders who wish to plant oil palm from accessing land, infrastructure, and credit. ${ }^{6}$ The Sarawak example shows rather clearly the pluses and minuses of collective tenure as a response to piecemeal dispossession: protection from the risks of the market on one side and exclusion from its benefits on the other.

\section{Colonial Africa}

Very briefly, and risking caricature in the interest of aa of comparative inquiry, I want to highlight a common thread that links my examples from Asia to Africa. In Africa too, colonial regimes invented collective tenures over customary land and attempted to suppress the commoditization of land as they looked for ways to develop commercial production without wholesale dispossession of the African population. They constructed concepts of community, tribe, and custom to "prevent, limit or otherwise manage dynamics of class formation" by returning urban workers to their chiefs, preventing chiefs from becoming a class of accumulators, and instructing Africans on how to lead appropriately African lives (Bernstein 2005:72 [emphasis in original]; see also Cowen and Shenton 1996; Mamdani 1996; Tiffen 1996).

A key intervention in much of Africa was the attempt to

are not secure: the Sarawak government recently suppressed maps of native customary land and banned "countermapping" by communities in an attempt to stem native claims (Colchester, n.d.:8).

6. Cramb (2007) reports that 8,970 requests flooded a smallholder support scheme in 2006; of these, $94 \%$ were to develop customary land, and none were approved; only 161 applications were approved, all on titled land. "reserve" some land for collective African use. This policy was supported-indeed prompted-by sections of the African population who looked to these reserves as a defense against further land loss to white settlement or expropriation. Reserving land for collective African subjects served multiple agendas, as Martin Chanock (1991) points out: (1) it justified white expropriation by confirming that Africans were too primitive to have a concept of individual land ownership; (2) it consolidated the power of the chiefs to whom colonial authorities attributed (and granted) a "customary" right to allocate use rights to "their" people; (3) it bounded and "tribalized" the population, effecting what Donald Moore (2005) calls the "ethnic spatial fix"; and (4) it restricted-although it did not prevent-class formation among African farmers.

The colonial land regime in British Africa hinged on the conviction that Africans held land "in some form of communal tenure, it could not be sold by individuals, and that all had a more or less equal right to land" (Chanock 1991: 63). British authorities deemed communal tenure to be both customary and optimal for the African population, while they deemed individualism, urbanization, acquisitive capitalism, and the commoditization of land to be improper. As late as 1946, a British official maintained the argument that "freedom to traffic in land" was ill advised in Africa, because it would create "an indebted peasantry and a landless class," repeating the mistake the British had made in India (Chanock 1991: 71; see also Berry 1993:104-110). Colonial officials could not fail to observe that African farmers, especially those involved in the production of commercial crops, were in fact buying and selling land. In the dynamic cocoa belt of West Africa, it was clear that these practices were so well entrenched they could not be reversed. But in many parts of Africa officials insisted that attempts to assert individual claims were contrary to custom, hence illegitimate. Conversely, an individual seeking to have a claim recognized as legitimate had to present it in the idiom of custom, even though new conditions were creating new aspirations, new practices, and new "customs" that the fixed framework of customary law could not readily accommodate. ${ }^{7}$ As Africans struggled over land in households, villages, courtrooms, and fields, colonial authorities conceded that land use was highly individualized; they stumbled over issues of inheritance and the rights of women to productive farms they had helped to develop; but they consistently rejected the concept of full individual ownership with the attendant right to sell (Chanock 1991:75).

Anthropologist Deborah James reports the cruel irony that landless South Africans today, frustrated by the slow pace of land reform in their country, look back favorably on the apartheid system of native reserves in which a racialized entitlement guaranteed them access to land, however crowded, in a way that the market does not. Contemporary land rights activists reject alienable title for the same reasons colonial

7. Berry (1993) stresses the gap between colonial land policies and what happened in practice. 
officials did decades ago: the risk of land loss through debt (James 2006:244-245, 263-265). ${ }^{8}$

\section{The Netherlands East Indies}

Dutch policies for governing land relations in the Netherlands East Indies were like those in British Africa in one respect: the Dutch treated the entire population as equally "native." The key distinction they made was racial, embedding the separation of Europeans from Natives and Foreign Orientals (many of them Chinese) in a legal and administrative apartheid comparable to the system instituted in South Africa a century later (Fasseur 1994). ${ }^{9}$ Unlike the British in India or the French in Vietnam (Salemink 1999) or the Americans in the Philippines (Eder and McKenna 2004), the Dutch did not divide the native population into peasants and tribes. Instead, the Dutch system for managing the native population built on a legacy left to them by the British governor Sir Thomas Stamford Raffles, who ruled the colony for a brief interregnum in 1812-1816, bringing with him the concept of the timeless Asian village republic still popular among British officials in India at that time. Raffles began the process of making the bounded village real by instituting a system to tax villages as collectivities and manage them through appointed headmen. Raffles was a liberal and a disciple of Adam Smith. He thought the Javanese were fully capable of becoming competent market subjects. He intended the village-based tax and property system as an interim measure before individualized tenure could be institutionalized. Instead, when the Dutch reestablished their rule in Java, they consolidated the village system to use it for a different purpose: as a means to administer a system of forced cultivation (see Breman 1983:6; Elson 1994: 24-25; Li 2007b:34-35).

Landholding arrangements in Java early in the nineteenth century were varied. In some areas, landholding was individual and included the right to mortgage and sell. In others, a portion of the land was held communally and reapportioned, a system imposed by local rulers as a way to maximize the tax base (Elson 1994:17-22). ${ }^{10}$ Thus, the Dutch attempt to communalize landholding built on a system that already existed in some areas. In other areas, communalizing tenure meant abrogating individualized rights. This occurred with particular drama and force in one instance in 1833, when

8. The many pressing problems surrounding communal tenure in South Africa, not least the abuse of authority by chiefs whose powers were entrenched in the apartheid period, are discussed in Claassens and Cousins (2008).

9. See James and Schrauwers (2003) for a discussion of connections between Dutch-designed apartheids in Indonesia and South Africa.

10. Similarly, in the Tonkin delta of Vietnam, precolonial authorities imposed communal tenure regimes on the peasantry with particular objectives in mind: "increasing the stock of labourers and taxpayers to meet the demands of the state," placing "reins upon the exercise of untrammeled power by wealthy and influential figures both inside and outside the village," and limiting "social disturbances" associated with land concentration (Elson 1997:124-125). "the Regent of Cirebon himself toured the region to collect the lontar leaves on which the title deeds were written and then had them burned" (Breman 1983:8). The Dutch consolidated the concept of the village as a landholding unit through the Agrarian Law of 1870, which declared that native landholding took the form of customary law communities (rechtsgemeenschap), with common "rights of avail" over a defined area of land. But the law and the associated Domain Declaration left the spatial scope of community "rights of avail" ambiguous, and Dutch authorities made no attempt to gazette village land or reserve it for native use. Unlike the Brookes in Sarawak, the Dutch excluded forests and fallows from the category of village land, leaving farmers with no room to expand cultivation and legitimating state appropriation of vast areas of land to be allocated to European-owned plantations or reserved as forests (see Burns 1989; Peluso and Vandergeest 2001).

The Dutch attempt to manage native land relations through a concept of harmonious village republics required a firm commitment to overlook some strikingly dissonant facts. Already in 1800 , when the Dutch crown assumed power in the colony and began to "govern" in the modern sense, rural landlessness was well established in lowland Java (Elson 1997: 123). ${ }^{11}$ Javanese farmers were highly indebted, a problem Dutch observers attributed to the natives' economic ineptitude on one hand and the rapaciousness of moneylendersboth Javanese and Chinese-on the other (Alexander and Alexander 1991). Money had been in circulation in rural villages from the ninth century (Boomgaard 1991:294). Again, the pattern varied, but some parts of the rice-producing lowlands were stratified into castelike estates of which the principal mark of difference was their ownership, or nonownership, of agricultural land. Landholding families legitimated their position by reference to descent from the founders who first cleared and settled the land. These families paid taxes to supralocal lords through intermediaries holding varying forms of tax farm or appanages. They organized production by incorporating landless farm servants as permanent dependents in complex households while also employing roving bands of "free" wage workers when needed. When the Dutch attempted to use the village concept to equalize landholdings and spread the tax burden, landholders resisted this intervention and found ways to keep landless covillagers under their direct control as dependent workers, creditors, and clients (Breman 1980, 1983, 2000; see also Elson 1994:17-22, 29-35, 162-170).

Although hierarchies were less entrenched on the forest frontiers of Java and the outer islands, the same elements were in play. "Founders cults" invoked divine sanction to restrict the right to clear land to descendants of the land pioneers and establish control over lucrative forest products (Lehman 2003). Landholders could incorporate newcomers

11. Numbers are sketchy for this period, but by some estimates the landless population was 30\%-50\% (Breman 1983:9). 
through mechanisms such as marriage or trap them in debt and keep them dependent, even in conditions of land abundance, especially if they arrived on the frontier without a stock of food or capital to maintain themselves until their first harvest (see Breman 2000:236; Elson 1994:20). Land pioneers were often sponsored and protected by overlords who extracted returns in the form of taxes or a monopoly on trade. In parts of highland Java and Sumatra, there was a lively commercial agriculture producing crops for world markets. In West Sumatra, for example, farmers were producing coffee for export by the 1790s, and numerous other cash crops rose and fell in importance before the Dutch established territorial control in 1837 and began to intervene in production (Kahn 1993:170-179). Even in the remote highlands of Central Sulawesi where I have conducted much of my fieldwork over the past two decades, farmers were producing tobacco for export by 1820 and were tied to their traders by relations of debt, all this a full century before any systematic form of Dutch rule reached the area ( $\mathrm{Li} 2001 b$ ).

In much of the archipelago, individuals who invested labor in land improvement by clearing forests, developing new rice terraces, or planting perennials acquired a strongly individualized right to the land and were involved in land sale and mortgage (Elson 1997:125-131). The right to sell was sometimes tempered, especially for the heirs in subsequent generations, by strictures favoring transfer within the groupvariously a kindred, a lineage, a village or comparable spatial unit- to the exclusion of outsiders. In Minangkabau villages early in the nineteenth century, for example, clan heads and village elders restricted land sale and attempted to keep transfer by mortgage within the lineage. There were elaborate schemes to prevent land concentration in the hands of some villagers (Kahn 1993:159-160). ${ }^{12}$ As I suggested earlier, these restrictions only make sense in a context where land alienation and land concentration had emerged as possibilities. If there was no one seeking to buy, mortgage, or otherwise monopolize land, restriction would be unnecessary.

By 1870, the Dutch recognized that coffee smallholders and wet rice farmers on Java were de facto owners of individual property. They taxed them individually. But they were not prepared to treat them as competent market subjects or to legitimate the individualization of land by issuing titles (Elson 1997:127; Hugenholtz 1994). ${ }^{13}$ Instead, like the British in India, they continued to debate the matter of native economies

12. Kahn (1993:163, n. 16) observes that coffee, as a perennial, "involved more permanent alienation of village land, thus creating conflicts between individual cultivators, village councils, and the constituent suku." See von Benda-Beckmann and von Benda-Beckmann (1985) for an account of uneven access to lineage property and the elaborate rules governing its transmission in the nineteenth century. Compare the restrictions aristocratic lines imposed on their covillagers in land-abundant Borneo (Eghenter 2000) and the range of land regimes in the "unhispanicized" Philippines (Scott 1985).

13. By 2004 , only about $30 \%$ of an estimated 80 million land parcels covering only $3 \%-5 \%$ of the total land area of Indonesia were titled (World Bank 2004:5). in general and land-tenure systems in particular. As in India, there were two main schools of thought, producing policies that leaned one way, then the other. One school, labeled liberal, argued that there should be one law for everyone in the Indies, colonizer and colonized alike, and one land-tenure system. Because natives had long been familiar with the concept of individual tenure, they should be free to register their land and sell it if they so chose. One law would treat natives as fully competent to know and pursue their own interest and subject them to the healthy discipline of market competition to their overall benefit. The other school, labeled conservative, argued that natives were not-and should not become- "normal" market subjects. Their worldviews and aspirations were quite distinct, their land was held collectively, and their ways of life and livelihood should be protected for a long period, perhaps permanently (these debates are reviewed in Burns 2004; Kahn 1993:75-109; Lev 1985:64-66; Wertheim 1961).

The idea of an Asiatic form of collective landholding was elaborated and given empirical support from around 1900 by Leiden law professor Cornelis Van Vollenhoven and his students, who began documenting customary law. According to Peter Burns (1989), these scholars started with the concept of a "customary law community" that had been enshrined in the 1870 Agrarian Law and proceeded to confirm that such communities, each conceived as a harmonious and organic whole, did indeed exist right across the archipelago and held a collective, inalienable right of avail over their territories. The scholars explained their findings in terms of a radical divide between the East and the West, a division congruent with the racial axis (native/white) that organized colonial relations. The Asiatic native worldview, they argued, was different from the Western worldview in every respect. For the natives, land was not a commodity but an integral element of social life, imbued with a sacred force embodied in spirits who would be upset by disruptions in social order and cause illness, death, and harvest failure. ${ }^{14}$ Needless to say, landlessness and exploitation among the native population, both before and since colonial intervention, had no place in this picture.

To protect native welfare-and pragmatically, to prevent disruption to colonial rule and commerce-Van Vollenhoven argued that the territories of customary law communities must be respected. In particular, he insisted that customary community rights of avail included forests and fallow land wrongfully appropriated under the banner of the 1870 law. His main concern was the large-scale seizure of native land for plantation use and the risk that "continued contempt for indigenous rights could lead to social upheaval, even to fullscale civil war" (Burns 1989:15). Already in 1870, provincial officials had recognized the risk of protest, and some had

14. Burns (1989:98-101) traces the origins of this orientalist organicism to the influence of the French writer Renan and the Germanic concept of a Volksgeist. See also Kahn (1993). 
quietly failed to publicize or implement the Agrarian Law. This occurred in West Sumatra, where Minangkabau lineage and territorial organization was especially strong (von BendaBeckmann and von Benda-Beckmann 1985:258-259). The concern was echoed in 1911 by J. Ballot, governor of Sumatra's West Coast, who weighed into the debate among colonial officials by publishing a book arguing for the recognition of customary territories and predicting that land grabbing for plantations would cause a rebellion. Ballot was dismissed, and in the following decade, the area of land allocated to plantations almost doubled (Kahn 1993:187-223). Some Sumatran highlanders were squeezed out of production altogether, but others moved off to the forest frontier and found ways to reconfigure their livelihoods on the edge of the plantation economy, intensifying land use with a mix of food and cash crops (Kahn 1993). Although they responded to new market opportunities, they were chronically short of capital and vulnerable to dispossession, especially through debt.

Geertz's book Agricultural Involution, which has been properly criticized for ignoring the substantial landless population on Java and overstating the static, communal character of Javanese village life (see Alexander and Alexander 1982, 1991; Husken 1989; Husken and White 1989; White 1983), nevertheless observed the rapid class differentiation that had occurred in the "outer islands" in the context of commodity production. He relied in particular on a study by the sociologist Schrieke, tasked by colonial authorities to discover why Sumatran highlanders flocked to the Communist Party in the 1920s. The reason, Schrieke argued, was their displacement by plantations combined with the rapid onset of processes of accumulation and dispossession among themselves as "coffee madness" brought spectacular profits for some and high rates of debt and land loss for others (Geertz 1963:120-123; Schrieke 1955). Schrieke observed that some highlanders, lamenting the decline of custom, "would like nothing better than to see the government decree the inalienability of land by law" (Schrieke cited in Burns 1989:15, n. 18). Ironically, as Burns points out, native land was inalienable by law in the 1920s, as it had been since 1870. Highlanders claimed individual rights to land nonetheless, with predictably unequal consequences.

Not all officials in the 1920s were convinced that inequality was a bad thing. In Java's densely populated rice and sugarproducing heartland of Cirebon, authorities experimented with a reverse land reform that involved taking the tiny parcels of land held by poor villagers away from them and allocating the land to the larger landholders in order to make the latter more efficient and prosperous and more capable of maintaining order in a restive countryside. Interestingly, the plan was not to give them full private ownership, only a fixed share in the communal land pool, in order to prevent land accumulation or dispossession among the recipients (Breman 1983:59). Another remarkable feature of this intervention was the apparent lack of concern among Dutch officials about how the newly dispossessed villagers would survive. The village myth was such that the Dutch had little data on the existing extent of landlessness or the limited willingness or capacity of the landholding villagers to offer employment. More curious still, the officials promoting this reform demonstrated no concern that the reform would inadvertently augment the disruptive forces it was designed to quell (Breman 1983:60, 94, 108-112).

In 1926, reviewing the causes of mounting rebellion in the countryside and considering means to prevent it, the colonial advisor Van der Kolff overlooked seizures of native land and class differentiation among farmers, in both of which Dutch policies played a role, and the long history of commerce in the archipelago. Instead, he focused on cultural otherness, a "too rapidly penetrating money economy in an agrarian community which until recently had been practically without it" (G. H. Van der Kolff, quoted in Kahn 1993:279).

Dutch myths about the natural Asiatic economy they had encountered and preserved traveled the colonial circuit. In the same year that Van der Kolff proferred his bizarre conclusions, a British official in Malaya, working on the land enactment to reserve land for Malays, cited the observation of an official in India to the effect that "the Javans have escaped that fatal gift of absolute proprietary right which has been the ruin of so many tens of thousands of our peasantry in India," adding that Javanese prosperity stemmed from "the inability of the Javan to raise one single florin on the security of his fields, and the protection thus enjoyed by him against the money-lender and against himself" (Kratoska 1985:29). On this note, I leave the comparative history of attempts to manage dispossession in the colonial period to take up the story ca. 2000, a period with echoes of colonial encounters.

\section{Managing Dispossession ca. 2000}

Constraints of space prevent me from tracking national trajectories in detail through the decades 1950-1990, which were dominated, in much of the global south, by two concerns: national development on the one hand and the Cold War on the other. In much of Asia, as Anna Tsing (2003) has argued, the concept of homogenous national peasants figured prominently in programs and debates. Peasants were sent into the uplands as the "territorial spearhead" of the state in order to tame unruly tribes and consolidate borders threatened by communist insurgency (De Koninck and Dery 1997). They were treated as potentially revolutionary subjects whose hunger for land and food had to be addressed. They were also expected to supply the labor, taxes, and surplus produce that would boost industrialization. As peasantries took center stage, the populations that had become marked as distinctly "tribal" in the colonial period were treated as a national embarrassment to be brought up to modern standards as quickly as possible (Tsing 2003).

The relative lack of attention to Asia's "tribal” populations changed in the 1990s with the end of the Cold War, increased 
democracy, and administrative decentralization, which together opened up a space for the reemergence of ethnopolitics. Another key factor was the new round of large-scale enclosures associated with the expansion of global corporate capitalism on the one hand and global environmentalism on the other (see De Angelis 2001; Glassman 2006; RETORT 2005). These enclosures were often rapid and brutal and more devastating to their victims than the major colonial enclosures of 1870-1910 because population density was higher and because they targeted the highlands and forests that previously served the dispossessed as a frontier for escape. Coincidently, these highlands and forests were also the areas that had become associated with "tribal" populations in the colonial period. As these economic and political pressures came together in a range of distinct national and local configurations, some of the afflicted populations began to articulate their resistance in the terms supplied by the global indigenous people's movement that gathered strength in the 1990s (see Barnes, Gray, and Kingsbury 1995 for an overview).

The issue of whether the category "indigenous people" applies in Asia has been much debated (see Beteille 1998; Bowen 2000; Karlsson 2003; Li 2000, 2001a; Vandergeest 2003; Walker 2001). In parts of Asia where colonial authorities had created a distinct legal category "tribe," as they did in India and the Philippines, the colonial category transmuted relatively easily into the transnational category "indigenous," at least from the perspective of the indigenous peoples' movement. In Indonesia, where the colonial regime did not divide the population into peasants versus tribes, the question of who is indigenous is wide open. Estimates of the "indigenous" population range from 1 to 120 million, depending on how the category is defined. ${ }^{15}$ In Malaysia, the ruling regime declared the majority Malay population "indigenous" in contrast to the labor migrants imported from China and India in colonial times, but it is reluctant to recognize the special claims of the Orang Asli, ancient residents of the Malay peninsula (Idrus 2008). In Africa, the indigenous peoples' movement has resonated with populations associated with nonagrarian livelihood strategies, such as pastoralist Maasai or San hunters and gatherers, while dispossessed San farm work-

15. The low number represents groups officially defined as "isolated and estranged" and targeted by a special program to bring them into the national mainstream. I discuss this program in Li (1999). Advocates in the 1990s put the number of "indigenous people" at 50-70 million, a number consistent with the "arborealization" of indigeneity that I discuss in "Agrarian Dispossession Revisited: Renewing the Communal Fix," because it originates from a study by legal advocate Owen Lynch, who estimated that 80-95 million Indonesians depend on forest resources and 40-65 million live on land classified as state forest (Lynch and Talbott 1995:22). The highest number comes from Colchester (n.d.:6), who links his definition of indigeneity to minority status flagged by linguistic diversity, or speaking "most of the 600 languages in the country." He states that Indonesia has 60-120 million people who see themselves as belonging to the category "indigenous" as defined in international law and who "claim rights to the collective ownership of their lands." See also Colchester, Sirait, and Wijardjo (2003:112-113). ers have found it more difficult to establish their claims (see Hodgson 2002; Igoe 2006; Sylvain 2002). The concept of indigeneity has also been mobilized by ethnic minorities such as the Ogoni of the Niger delta, who are struggling to hold onto valuable resources, in this case oil (Watts 1999).

It is worth noting that debate over the meaning of indigeneity is not confined to the awkward cases of Asia and Africa. Debate extends to the white settler colonies, where the feature I have been discussing in this article-collective attachment to inalienable land-is also brought into play. In New Zealand, for example, under interpretations of the Treaty of Waitangi Act (1975) that emerged in the 1990s, only "tribal" Maori who can trace their links to a tribal group and a tribal territory are recognized as indigenous, and only they benefit from restored collective rights to these territories. Maori farmworkers and urban dwellers, dispossessed of both land and family histories through generations of violent displacement, are classified as ethnically Maori but not indigenous (Rata 2002). ${ }^{16}$ In Bolivia, as Nancy Postero (2006) shows, struggles between contending "indigenous" groups hinge on establishing links between collectivities and territories. In the United States and Canada, groups "on reserve" have a different legal standing from individuals of native/Indian descent who are detached from a collective territory. Put differently, in many contexts, the only properly indigenous person is a person embedded in a group and a place. Contemporary transnational definitions confirm these links. The United Nations Declaration on the Rights of Indigenous Peoples highlights the "collective rights which are indispensable for their existence, well-being and integral development as peoples" (United Nations 2007:3). All the rights outlined in the declaration pertain to groups, not to indigenous persons as individuals. Similarly, the World Bank's 2005 revision of $O p$ erational Policies: Indigenous Peoples "recognizes that the identities and cultures of Indigenous Peoples are inextricably linked to the lands on which they live and the natural resources on which they depend" (par. 2) and further that this identity and the attendant rights are collective (World Bank 2005, par. 4).

From the array of mechanisms through which capitalism is linked to indigeneity and dispossession, the one that stands out in the contemporary period is the one I noted at the outset: indigenous people up against wholesale displacement by dams, plantations, and other megaprojects. People resisting these projects who can argue that it is not just livelihoods but culturally distinct and ecologically sound ways of life that are being destroyed have captured public attention. The safeguards for indigenous people put in place by the UN rights regime and by the development banks are designed to respond

16. Webster (1998) describes colonial debates pitting the need to protect Maori from dispossession versus settler demands for Maori land and labor. He argues that processes of proletarianization, peasantization, and tribalization were concurrent and shaped by the differentiated form of capitalism in New Zealand. 
to the mass-displacement scenario. When compared to officials in the colonial period, activists and authorities who take responsibility for "governing" today are much less explicit about the dispossessory effects of capitalist processes emerging "from below." In the next section, I explore the reasons for the impoverished debate on the "downsides" of agrarian capitalism and examine two current attempts to consolidate collective "indigenous" tenure regimes by reworking colonial models for novel ends.

\section{Agrarian Capitalism and the Poverty of Analysis}

One reason why the virtues of capitalism are not much debated today is the widespread view that the market has triumphed: there is no alternative (Watts 1994). The World Bank, among others, continues to proffer an unrevised market fundamentalism that diagnoses poverty as the result of insufficient market integration and prescribes more complete market integration as the cure. This diagnosis-prescription chain conjures up, once again, the figure of the subsistence farmer in a natural economy who lacks market opportunity. This figure is personified in the image of an "African woman bent under the sun, weeding sorghum in an arid field with a hoe, a child strapped on her back," to quote from the first sentence of the World Development Report, Agriculture for Development (World Bank 2008:1). The report recommends that farmers unable to compete in the world of commercial agriculture should stop trying to farm and migrate to cities or look for wage work. It offers no discussion of the social movements that have formed to resist eviction or reclaim land for the landless, hence it fails to recognize the strength and vigor of these movements as a reflection of the important role that land still plays in providing a modicum of security in a drastically uncertain world (Moyo and Yeros 2005). The political threat that large numbers of dispossessed people might pose to ruling regimes - an important concern in the colonial period and during the Cold War-does not figure in the bank's analysis.

The collapse of socialist versions of collective agriculture further contributes to the sense that there are no alternatives, hence nothing to debate. It is worth recalling, however, that the rationale of the Vietnamese Communist Party for imposing collectivization in the 1960s was not a doctrinaire position on the virtues of collectivism. Rather, it was the pragmatic recognition that the first wave of land reform the party carried out in the 1950s, the distribution of land to individual peasant households, rapidly slid backward as land was again concentrated through the mundane mechanism of debt. As a commentator observed in 1964,

A drought, a heavy rainfall, the illness of a buffalo or of a member of his family - things quite frequent in Vietnamsuffice to compel the peasant to go into debt and sell part of his property. . . . To the economic processes of differentiation of social classes under the regime of individual exploitation, one must oppose, not coercive or repressive measures, but the conversion of economic structures, the setting up of new production relations. (Published under the name "N N" in Vietnamese Studies and quoted in Jorgensen 2006:165.)

Vietnamese collectivism, as we now know, also slid backward, as peasants insisted on their right to engage in marketoriented production and succeeded, through their "everyday resistance," in persuading the regime to recognize the de facto reprivatization of land and labor they had already implemented (Kerkvliet 2005). The outcome has been increasing inequality in access to agricultural land, albeit with important regional variations (Akram-Lodhi 2005; Sikor 2001). ${ }^{17}$

A second reason for the impoverished debate about capitalism is the resolute focus of activists in the global peasant movement on the macro, transnational, or "global" scale. Thus, the analysis supplied by La Via Campesina, for example, locates the problems afflicting rural people in the figure of the transnational agrofood corporation. In particular, the movement highlights the regime of tariffs and subsidies that supports these corporations at the expense of small-scale farmers whose subsidies were withdrawn in the name of "structural adjustment" and the efficiency of "free" markets. The movement offers little analysis of processes of dispossession that arise among small-scale farmers (see La Via Campesina and FIAN International 2006; Rosset 2006). Its scholar activists, heirs to what Terence Byres calls the "neopopulist" tradition, argue for redistributive land reform on the assumption that small-scale farmers, once they are given land, would hold onto it, and "nowhere consider the possibility that the redistributive land reform that they advocate might, if it were successful, lay the basis for capitalism from below; might create structures within which processes of differentiation flourished and a class of capitalist farmers emerged" $(2004: 30){ }^{18}$

Presumably, the macrofocus of the "neopopulist" stance of the global peasant movement and its reluctance to examine microprocesses of dispossession among small-scale farmers are strategic. Many people who are comfortable with smallscale capitalism and describe it in populist terms (income generation, local business, entrepreneurship) are convinced that big corporations are evil and should be stopped. The peasant movement needs strong, clear images that can mobilize a broad constituency both in rural areas, where too

17. Anticipating renewed inequalities, the Vietnamese government has not granted individual ownership but only time-limited "use rights," which can be redistributed in the future.

18. See also Bernstein (2004). Some national governments engaged in distributive land reform or state-land allocation recognize the risk of renewed inequality and attempt to forestall it by forbidding land sale in the initial years. See Hetherington $(2008,2009)$ for an example from Paraguay and Borras (2006) and Hall, Hirsch, and Li (forthcoming) on Southeast Asia. Ellsworth (2002:12-14) provides a useful review of populist and other perspectives on the pros and cons of individualized tenure. 
much attention to class differentiation would be divisive, and in the cities, where components of the urban middle class support the movement out of nostalgia for wholesome rural ways of life. The transnational indigenous peoples' movement is even more constrained, because urban people expect indigenous people to be authentic bearers of cultural difference and ecological wisdom, a salve to their anxious modernity. Class differentiation among indigenous people, whether small-scale farmers or the "neotribal capitalist" corporations in New Zealand starkly described by Elizabeth Rata, runs counter to this image, as do the U.S. and Canadian natives who make use of their distinct legal status to build casinos or Amazonians who sell off their timber instead of conserving it. ${ }^{19}$ Theirs are not heroic stories, so it is not surprising that indigenous peoples' capitalist practices do not figure strongly in the movement's public transcript.

In the preferred narrative of the indigenous peoples' movement, indigenous people are the victims of capitalist processes intruding from the outside. Some advocates suggest that indigenous people still have difficulty handling money and are easily impoverished by debt, enticed by consumer goods, or tricked by incoming migrants, entrepreneurs, or officials into selling land for a pittance. They are also sold out by their leaders when indigenous systems to check abuses are undermined (Colchester, n.d.; Colchester et al. 2006:15-16). They need "more time to adjust to market pressures" (Lynch and Harwell 2002:5). They also need a protective legal regime that supports collective tenure. Naming the state as the principal villain, Marcus Colchester argues that "it is state denial of communal rights that causes land ownership to be fragmented and individualized, and traditions of custodianship and resource management undermined" (1994:76). Based on consultations with indigenous groups, he is convinced that they want "the right to collective ownership of their communal territories. They want legal recognition granting them inalienable freehold title to their ancestral domains" (Colchester 1994:72; see also Lynch and Harwell 2002). With their land rights entrenched, he suggests, these communities would stay intact. He recognizes that there are countervailing desires for individualized tenure among people who want to engage in entrepreneurial, profit-making, and potentially accumulative agriculture, but he points to many examples in which individual tenure has led to loss of land, livelihood, and cultural integrity. It is, in short, a risky path (see AMAN, World Agroforestry Centre, and Forest Peoples Programme 2003; Colchester et al. 2006).

\section{Agrarian Dispossession Revisited: Renewing the Communal Fix}

The two contemporary iterations of the communal fix I examine in this section are designed to protect selected groups

19. On New Zealand, see Rata $(2003,2002)$. On urban imaginaries of authentic indigeneity, see Conklin and Graham (1995), Ellen (1986), Povinelli (1999), and Ramos 2000. of rural people from the risk of dispossession while offering them the benefits of market involvement. One version has been put forward by the World Bank, as a modification of the stance that advocates full market integration for everyone, everywhere. Like colonial authorities, and building on their work, the World Bank has started to divide populations and promote a diversity of tenure regimes suited to the cultural proclivities and capacities of particular groups. Citing research by anthropologists on the impoverishing effects of land titling in Africa in the 1970s and 1980s, the 1990 World Development Report (World Bank 1990) proclaimed the bank's rediscovery of the virtues of collective tenure. The report acknowledged that the "shift toward individual rights tends to undermine the ability of traditional systems to ensure that all members of the extended family have access to land. This feature of their land system has helped some countries in Africa to avoid the extremes of poverty and landlessness that are common in much of Asia and Latin America" (World Bank 1990:65). Using indirect language that carefully avoids holding the bank responsible for an erroneous policy that intensified the dispossession of the poor, a report by consultants for the bank stated that "the economic arguments for individual rights have been reassessed and it is now suggested there is little evidence that customary tenure arrangements are a constraint on agricultural productivity." Not only is individualized tenure unnecessary from the perspective of efficient production, the consultants observed, it can have unintended negative effects, as it is linked to "increased landlessness as land markets develop, the fact that people may be encouraged to sell their land for short-term returns, and 'land grabbing' by the social elite or those with privileged access to information and formal institutions" (Land Equity International 2003:86, 87; see also Deininger and Binswanger 2001:418-419).

In view of these findings, the World Bank began to look favorably on collective titles for indigenous groups in Asia and Latin America as well as in Africa (Deininger and Binswanger 2001:417-420). It committed itself to preserving the collective tenure systems of indigenous people, unless the people concerned opt for individual title (World Bank 2005, par. 17). The ideal collective tenure system for the bank combines the insurance or "safety net" function of collective rights to inalienable land with measures to encourage efficiency. The bank vision does not share the moral doubt about the virtues of capitalism that surfaced in some colonial debates. It promotes capitalism while seeking to manage its dispossessory effects. A collective tenure system that recognizes and rewards the investment of individuals in land improvement, and permits transfer within the group by means of inheritance and "exchange" provides, in bank thinking, an optimal balance of protections and incentives. It is even better when there are mechanisms for the group to convert to full individual tenure when the time is right. Sadly, bank experts observe, many collective tenure systems have been weakened by encroachment of "outsiders" or are administered by rapacious chiefs in an unfair or corrupt manner (Deininger and Binswanger 
2001:417-420). In these situations, individual tenure is inevitable, and the best that can be done to protect smallholders is to devise better systems of information, insurance, and credit to protect them from "shocks" and "distress sales" (Deininger and Binswanger 2001:427). At this point, the bank joins hands with the "neopopulists" of the global peasant movement I described earlier to treat the separation of small farmers from direct access to the means of production as an unfortunate accident from which wise policy makers should protect them. Once again, the analysis of the dispossessory dynamics of agrarian capitalism is seriously truncated.

The second renewal of the communal fix I want to explore here builds on the advocacy of the 1980s and 1990s that began to link indigeneity and the promotion of collective tenure regimes to the objective of forest conservation. Like the renewed communal fix at the World Bank, the latest iteration of the indigenous people and conservation platform ca. 2000 is distinctly market focused. It circumvents the problem of defining who is indigenous by stringing the concept of indigeneity together with allied terms such as local people, forest dwellers, or forest-dependent communities. All these people, proponents argue, are culturally distinct in the sense that they are embedded in communities and attached to forests. But they are not disconnected from markets or uninterested in profit. The goal of the program the advocates propose is to link indigenous people and other "forest dwellers" more firmly to markets as a means to secure both their livelihoods and forest conservation. But for the plan to work, these people must not be granted individualized, alienable title to their land.

Two transnational advocacy groups promoting the marketoriented conservation agenda are Forest Trends and the Rights and Resources Initiative. They set out explicitly to change the format of indigenous reserves pioneered in Brazil that "give indigenous peoples a place to live and a place to practice their traditional livelihoods" but do not empower them "to use their resources in a commercial manner" (Ellsworth and White 2004:32). The solution they propose is to give "indigenous communities" full legal title to their collectively owned forests so that they can sell goods and services derived from these forests, especially "ecosystem services" such as biodiversity protection, watershed management, and carbon sequestration (Ellsworth and White 2004). The special virtue of these particular services from the perspective of this advocacy agenda is that they can be supplied only so long as the forest remains intact. Hence, they give indigenous communities a built-in incentive to maintain their forests rather than logging or farming them, leasing them out, or dividing them up into individualized parcels.

Advocates for this new version of indigeneity, with its particular way of rationalizing the attempt to fix a group of people firmly onto the land, concur on a central point: "indigenous" and "forest-dwelling" people should not become capitalist farmers. Indeed, the advocates' reports contain almost no discussion of agriculture or agrarian livelihoods. Their discussions of the individualization of land tenure among in- digenous groups highlight corrupt implementation and the tendency to land loss (Ellsworth and White 2004:14-15). The implication is that commercial agriculture is a practice from which indigenous people can only lose. One document mentions " 350 million indigenous and tribal people who are entirely dependent on natural forests" (Rights and Resources Initiative 2005:1). In this advocacy agenda, it is not just agrarian capitalism that is occluded but farming in toto, presumably because farming is ( $a$ ) usually individualized, $(b)$ associated with the individualization of land tenure, and $(c)$ in competition with forest conservation. It is an agenda in which the livelihoods of indigenous people are, in the words of anthropologist Andrew Walker, firmly "arborealized" (2004). Further, they are collectivized and pinned to inalienable land.

In Indonesia, where Forest Trends has linked up with activists who have long been protesting against the unilateral appropriation of villagers' land by the Forest Department, advocates describe villagers" land use practices as "community managed agroforests" (Contreras-Hermosilla and Fay 2005: iii). This label both arborealizes and collectivizes. It strengthens the advocates' argument that any land currently claimed by the Forest Department that is restored to villagers should not be granted to individuals but only to communities. The advocates are explicit in this rationale: collective ownership will protect indigenous people from impoverishing themselves by selling their land; it will supply them with an incentive to manage the forest because they will be attached to it on a permanent basis; it will also help to convince the Forest Department to release land to villagers, something the department has thus far refused to do on the grounds that villagers would promptly sell it (Contreras-Hermosilla and Fay 2005:20). ${ }^{20}$

The point overlooked by the advocates is that the people they describe in arborealized terms as "forest dwelling" or "forest-dependent communities" are also farmers. They have permanent fields growing wet rice. They also have groves of commercial tree crops that have been pervasive in the region for at least one century and sometimes two. Further, they claim these tree crop groves as their individual property, theirs to mortgage or sell should the need arise. Thus, there is a disjuncture between the advocacy platform and the sense people have of their entitlement. This is a disjuncture that also exists among villagers, some of whom support the commoditization of land while others oppose it.

In an interview with indigenous rights advocates, one Dayak leader who has been prominent in the indigenous peoples' movement in the Indonesian island of Kalimantan made his argument for reasserting community control in these terms: "The ideal concept is to have community control of customary land. The proper application of adat means lands

20. Down to Earth (2003) reports an incident in which the forest minister made this argument at a dialogue session with a donor. Delegates from Indonesia's indigenous peoples' movement walked out, protesting that they have traditions of forest protection. They did not respond on the issue of land selling. 
are never sold. But what is happening is that people are being forced to sell their lands" (Colchester 2005:15). Asked by the interviewer how he would accommodate the fact that Dayak rubber smallholders have been buying and selling land for more than 30 years, he said "the principle must be that customary lands belong to the collective. So if there are actors who sell and buy the principle must be enforced. The land must not be seen as empty. The land has its own value and is filled with spirit(s). It cannot be seen as just land. It has precious values and strong spiritual meaning. People who have sold their land must be fined and sanctioned for these actions" (Colchester 2005:15).

I read the Dayak leader's words as an attempt to counter dispossession by making land inalienable. It is not a statement of what exists - community control — but a statement of what should exist. It is framed as a restoration of a past state before land markets intruded, but the problem of community control arises only because a land market has, in fact, intruded. The leader notes that people are forced to sell land. Presumably, these are farmers on a downward spiral, crushed by debt, who cannot make ends meet-classic victims of the "simple reproduction squeeze." But the leader does not name this problem. Instead, he wants to govern their conduct by punishing them for their actions or encouraging them to make a different choice. Choice, however, is a privilege. Several of the Dayak leaders interviewed for the report who oppose land selling had steady incomes from careers as government officials and hence other ways to raise cash even if their farms did not pay.

\section{Conclusion}

In the contemporary period, indigeneity as a vehicle to counter dispossession has had some traction, especially where it has enabled people to resist large-scale enclosures and mass eviction. It has had less traction among small-scale farmers, who are eligible for the special protections associated with indigeneity only if they are able and willing to conform to a model of landholding that is collective and inalienable. Protection and incarceration are two sides of the same coin. As I have noted, collective landholding is sometimes imposed by a local group on its own members because they recognize the risk of dispossession and seek to prevent it. More often, however, it has been imposed from outside, first by paternalistic officials of the colonial period and now by a new set of experts and advocates who assume responsibility for deciding who should and who should not, be exposed to the risks and opportunities of market engagement. However, from the perspective of their proponents, attempts to consolidate collective landholdings are not impositions at all. They simply confirm a culturally distinct formation naturally present among indigenous people. ${ }^{21}$ Thus, attempts at economic governance

21. In Li (2007b), I provide an extensive discussion of the style of governing that attempts to improve communities by restoring them to their authentic state. produce a discourse on alterity that overlooks the dynamics of dispossession-the very same dynamics that call indigeneity-as-collectivism into being.

Like their colonial predecessors, contemporary advocates seeking to protect indigenous people do not attempt to reverse the dispossessory effects of capitalism overall. Rather, they seek to erect a wall-less extreme than the wall the British built around the Rajmahal Hills, but a wall nonethelessguarded by the insistence that indigenous peoples' landholding is collective and inalienable. Such a wall leaves the world beyond its boundaries unchanged and confines those inside the wall to a set of constraints many of them reject, as they have shown by their actions over more than a century. Just as some people who consider themselves indigenous reject individualized tenure, others insist on their right to buy, sell, and mortgage their land. This cannot be seen simply as a matter of choice. When there is a choice, it is shaped by a desire and expectation that capitalist agriculture will produce good returns, money to educate children, and other benefits. All too often, however, it is a matter of compulsion, as farmers subject to the "simple reproduction squeeze" do not take loans with dispossession in mind, only with the desperate need for cash. Liberal notions of choice serve to distance would-be governors from the charge of paternalism, but they bear scant relation to the fierce constraints of everyday survival. The notion of choice by a collectivity is still more problematic. Under the UN indigenous rights regime and the consultation mechanisms of the development banks, self-determination is indelibly collective. If a group is fractured, or favours individualized property, or an individual acts alone, indigenous rights that are contingent on the existence of a collectivity evaporate.

The task of "government," as I have shown, requires a difficult balance between multiple objectives, and the matter of how to govern in the name of what set of values or visions of improvement is continuously up for debate. Anthropologists have played a prominent role in these debates, especially when they concern the character and capacities of rural populations, the subject of anthropology's special expertise. At times, anthropologists have promoted strong concepts of community, indigeneity, race, or cultural difference, especially when these appeared to have strategic value in advancing an agenda they support. ${ }^{22}$ At other times, anthropologists have worked to loosen the hold of these concepts when they seemed to be doing harm. An excellent example of this kind of correction is the essay by Pauline Peters (2004) in which she points out that the work anthropologists had done in the 1970s and 1980s to highlight the adaptability of customary property regimes in Africa, a strategic intervention at a point when these regimes were being deliberately undermined, had begun to backfire. Authorities with jurisdiction over land matters began to argue that they did not need to worry about

22. For discussion of anthropology and "strategic" essentialism, see Brosius (1999), Hale (2006), Ramos (2000), and Warren (1998). 
dispossession because Africans had customary ways of sorting out land problems among themselves. But the forces producing dispossession in the African countryside Peters examined in the 1990s included violent eviction by paramilitaries, land grabbing by state-linked elites, and the effects of a global price regime that devastated farm-based livelihoods. No amount of creative adaptation from below could shield rural people from the effects of these processes, still less reverse them.

Continuous exposure of the diverse and changing forms of dispossession, I would like to suggest, is one of the more constructive interventions anthropologists can make today. Dispossession, to use Gillian Hart's trenchant phrasing, must be denaturalized (2006). In addition to the large-scale enclosures that continue to wreak havoc, as I noted at the outset, studies of dispossession must include what Mike Davis (2006:181) calls the "relentless micro-capitalism" of the poor that is a pervasive feature of their livelihoods in cities and countryside alike. They must also attend to the dispossessory and accumulative practices of "indigenous" elites and "customary" authorities, whose position was strengthened by colonial indirect rule and is increasingly entrenched. ${ }^{23}$ Though we all live in a generalized capitalist system, capitalism is not a singular form or a singular force. It is an assemblage of disparate elements, practices, and processes each with its own history of violence, law, hope, and struggle. We cannot tame it by building walls or wishing it away. Rather, we need to understand how it works in all its dynamic specificity. This is a field of study to which anthropologists have much to contribute.

\section{Acknowledgments}

I first presented this paper at the 2007 American Anthropological Association presidential panel "Indigenous Experience Today" sponsored by the Wenner-Gren Foundation. Thanks to the foundation and the organizers, Orin Starn and Marisol de la Cadena. I received excellent input on the draft from colleagues at the University of Toronto through the Markets and Modernities Colloquium at the Asian Institute, the Department of Anthropology Discussion Series, and from participants in seminars at the University of Northern British Columbia, the University of California, Berkeley, and the Central European University. Special thanks to Franz von BendaBeckmann, Derek Hall, Kregg Hetherington, Gavin Smith, and the journal's external reviewers for detailed written comments that saved me from many errors, though no doubt some still remain. Teaching release that enabled me to work on this project was provided by the Social Science and $\mathrm{Hu}$ manities Research Council of Canada.

23. See, e.g., Marcus Colchester's important discussion of the dangers of "lairdism" among indigenous people (1994), Pauline Peters's review of the role of chiefs in dispossession in Africa (Peters 2004), Elizabeth Rata's discussion of "neotribal capitalism" in New Zealand (2002), and Roger Sandall's strident critique of what he calls "romantic primitivism"(2001).

\section{Comments}

\section{Baviskar Amita}

Institute of Economic Growth, Delhi University Enclave, Delhi 110007, India (amita.baviskar@gmail.com). 18 XII 09

Dispossession and displacement have been a constitutive part of adivasi (tribal) subject formation in India from colonial times. After independence in 1947, these processes have accelerated first as a consequence of intensive resource extraction under the sign of state-led national development and, subsequently, neoliberal policies driven by corporate capitalism. As Li points out, the experience of displacement has been accompanied by the fixing of indigenous identities in place; legal provisions such as Schedules V and VI of the Indian constitution recognize the specific disadvantages and vulnerabilities of adivasi populations and seek to ameliorate them by restricting land transfers and reserving electoral representation in scheduled areas. However, these legal safeguards have largely proved ineffectual. In Schedule $\mathrm{V}$ areas of central India and Schedule VI areas of northeast India, increasing differentiation within tribal groups is reflected in the emergence of a political and economic elite that has used the levers of electoral and bureaucratic office to partner with nontribal industrialists and contractors, thereby garnering the lion's share of revenues from resource flows while the majority of the population has gained little. Such land and resource alienation could occur because the law failed to acknowledge and address the existence of inequalities among adivasis and their embeddedness in ongoing processes of commodification under capitalism.

While Li's argument about "the communal fix" being undermined by "capitalism from below" is an important insight into the tribal predicament in the Indian context-and one that is often ignored for the reasons that she explains- the primary contradiction that she highlights is between communal-tribal and individual peasant identities. However, processes of dispossession are enabled by another, overriding contradiction that pits two different forms of communal identity against each other, that is, the tribe versus the nation. Land alienation is effected by the state through its power of "eminent domain" exercised in the name of the community that supersedes all others - the nation. National development legitimizes projects that displace as "public purpose," superimposing on the rights of the "tribe" a more powerful communal identity with interests that supersede those of the "little community." The discourse of the nation enfolds all citizens into its rubric even as some citizens are regarded as more equal than others. This misrecognition of a differentiated public with conflicting interests and identities obscures the deeper cleavage and contradiction between tribe and nation.

The social mobilization against displacement by development projects has sought to strategically deploy the essen- 
tialisms of both tribe and nation to political effect, simultaneously claiming primordial attachment to land and territory as well as asserting rights of citizenship and equal treatment under the law. But the claim that adivasi communities have an enduring cultural orientation toward communal use and management of land is a public fiction: its performance by campaigns against displacement is accompanied by the tacit knowledge on both sides - the state as well as activists - that the collectivity contains individualized and at times conflicting interests. A notable example of this is the Scheduled Tribes (and Other Traditional Forest Dwellers) Recognition of Forest Rights Act of 2006, a path-breaking legislation granting adivasis individual land rights to areas controlled by the state Forest Department. This law goes against the grain of both state monopoly over forests for "public purpose" and "the communal fix" in order to legitimize the individual claims of adivasis as peasant cultivators. By the end of 2009, 2.5 million adivasis had filed claims seeking a conversion of "public" forests to private farm lands and in more than $20 \%$ of the cases had received land titles. The process is still under way, and many more claims are likely to be recognized in the near future. However, the law, which was drafted by tribal activists, places the responsibility of "sustainably" managing these forestlands on adivasis, enjoining them to desist from extractive or commercial use even though it does not specify any mechanism for enforcing this condition. In addition, tribal-rights activists lament that the law's provision for making communal claims to manage forests has not been pursued as vigorously as the provision for private land ownership. Only 22,000 community claims had been filed by November 2009. Thus, the collective enframings of both "nation" and "tribe"-publicly subscribed to by the state as well as rights activists-have been quietly jettisoned in favor of granting individual land rights. The substantial gains that adivasis have made through this act and are likely to make in the future exist alongside equally powerful countervailing moves toward displacement by land acquisition for dams, mining projects, and industrial enclaves called Special Economic Zones. These contradictions reflect the workings of democratic electoral politics in a country defined by sharp social inequalities. While adivasis may deeply desire individual land rights as critical to their social security, their ability to hold on to them is more tenuous than ever.

\section{Rob Cramb}

Faculty of Natural Resources, Agriculture, and Veterinary Science, University of Queensland, Level 5 Hartley Teakle Building, St. Lucia, Queensland 4072, Australia (r.cramb@ uq.edu.au). 24 XI 09

Contemporary debates about land policy with respect to "indigenous" or "customary" lands will benefit greatly from this insightful review. I am in broad agreement with Professor Li's argument, but there are some threads that invite further teas- ing out. I will raise two points, focusing on upland Southeast Asia.

First, from where did colonial scholar-administrators in Southeast Asia derive the idea that collective management of land was the norm among the indigenous communities they sought to govern? Clearly, it was not from British or Dutch norms or practice in the metropolitan countries. Rather, the idea came predominantly from observations of customary practice within the colonial territories and an extensive sharing of these views across the colonial world. However, the thoroughness of these observations varied, as did the degree to which they were distorted by preconceived ideas about the natural order in "primitive" societies. In particular, an oversimplified contrast between "communal" and "individual" land tenure pervades much colonial writing, as well as that of many modern-day policy analysts.

However, the reality of customary collective forms of land tenure was more complex than this binary view implies. Typically, individual and common rights coexisted in a complementary fashion within an overarching framework of community governance based on shared access to a defined territory. Individual rights to farming land and semicultivated trees sat alongside common rights and obligations to streams, forest reserves, and village infrastructure. This spectrum of rights was underpinned by shared rights to a territory collectively controlled and defended. The modes of land administration within this territorial complex varied, both spatially and temporally. Plots of farming land may have been held exclusively by individuals or households or rotated within a descent group or periodically allocated by a village head or council. Valuable trees may also have been held exclusively or shared by a descent group or an entire village. Ter Haar's (1948) compilation accurately reflected this more complex picture as did other more observant scholar- administrators such as Richards (1961).

Second, if forms of collective tenure were indeed important in many precolonial upland societies, what was their rationale? Professor Li expects that "an emphasis on collective tenure over agricultural land would arise only at the point when land becomes scarce, a land market is emerging, and alienation becomes a real possibility." Referring to a contemporary Indonesian Dayak leader's statement of the need to enforce customary tenure, she writes: "It is framed as a restoration of a past state before land markets intruded, but the problem of community control arises only because a land market has, in fact, intruded." In my view, this argument needs to be refined by distinguishing extensive and intensive types of farming. A compelling "premarket" reason for collective management of land was the competition among mobile autonomous communities for the extensive territories required to support swidden agriculture and the hunting and gathering activities that remained important to swidden-based livelihoods.

Dayak swidden cultivators in Borneo all established territorial control over the regions they moved into, displacing or 
absorbing hunter-gatherer groups in the process. They used armed force to establish and defend territorial boundaries, which included cultivated land and forest reserves. Within these territories, Dayaks generally recognized permanent household cultivation rights, reflecting the initial investment of labor in clearing old-growth forest. The scarce resource in this agroecological context was not land as such but cleared land, and collective management was an effective way to acquire and protect it.

Moreover, this form of collective management was compatible with the incorporation of smallholder cash crops in the uplands from the late nineteenth century. Professor Li writes that the British in Southeast Asia "were repeatedly surprised, and horrified, by the willingness of farmers in these [uplands] to take up production of 'boom' commodities such as rubber, coffee, and coconut and their rapid slide into debt resulting in the mortgage and sale of land." But farmers in British Borneo participated in these booms without disrupting the collective system of land administration; the coexistence of individual rights to land and trees and common rights to other resources was already the norm. And there was not wholesale descent into debt and dispossession in this region.

The long-term importance and apparent success of collective land management in such upland settings contrasts with the contemporary clash over land rights in Sarawak. In this context, many Dayak communities do in fact want legal recognition granting them "title to their ancestral domains." This is not to protect them from "market encroachment" as such but from government-endorsed expropriation by logging and plantation companies. What limited recognition the Brooke regime gave to territorial rights has been swept aside in recent decades. The struggle to protect and restore collective rights is not seen as a return to a precapitalist past but is pursued so that individuals within the community can undertake both subsistence activities and profitable commercial activities, including smallholder and group oil palm planting. It is indeed the case that the breakdown of collective tenure arrangements due to draconian government laws and policies is creating poverty and dispossession, engendering an intense legal battle for recognition of customary territorial rights. Perhaps this is Polanyi's double movement after all.

\section{Kaushik Ghosh}

Department of Anthropology, University of Texas at Austin, C3200, Austin, Texas 78712, U.S.A. (cayocan@mail.utexas .edu). 5 II 10

Indian activists organizing against adivasi (indigenous) dispossession have often addressed the question of "going beyond the Dam." It means that the microscopic processes of marginalization (e.g., indebtedness) need to be addressed "beyond" the prominent struggle against large-scale dispossession. Interestingly, several such activists had initially organized against what Tania Li calls "the dispossessory dynamics of agrarian capitalism.” But witnessing how indigenous laborers who had struggled out of debt bondage and won "inalienable" land ownership in the 1970s soon lost that land to a "largescale enclosure" (dams/mines/townships) and returned to indebtedness, they joined the emerging movement against macroscalar dispossession. India's adivasi movements thus do not read the macro- and microscales of capitalism as mutually exclusive. The Narmada Bachao Andolan, for example, has made several micro interventions - in schooling, irrigation, and electricity generation-parallel to their better-known struggle against big dams (http://www.narmada.org/ALTERNATIVES/).

I see Tania Li's essay as standing in an ambivalent relationship to the above spirit of the struggle against indigenous dispossession. It sharply points to the newer fault lines in indigenous communities created by the essentialism around collective land tenure in what I would call "transnational indigenous governmentality" (TIG; the example of Forest Trends was very apt). It is a welcome and necessary critique. The question of agrarian capitalism's daily and quotidian exploitation of indigenous peasants remains central to any serious indigenous political process. However, the essay seems to bear several negative effects of being determined in opposition to those same essentialisms. If the reifying notion of inalienable, collective land ownership is an essentialist trope of TIG, this should not imply the following.

1. Indigenous people have not consistently demanded sovereignty over land. After all, it cannot be emphasized enough that most often indigenous movements themselves have been the primary drivers of these demands, which then have been reterritorialized under different colonial/postcolonial/transnational governmental regimes of recognition (here it could be noted that the essay has inverted the historical logic of the Santal Revolt, where the Revolt's demand of eviction of exploitative outsiders - who were freely allowed and encouraged to enter this territory by British law-had to be acknowledged by the colonial state and not the other way round); the gap between the "indigeneity" of such governmentalities and what various heterogeneous indigenous actually claim needs to be mapped.

2. Indigeneity's truth instead lies in the fact that "just as some people who consider themselves indigenous reject individualized tenure, others insist on their right to buy, sell, and mortgage their land." This is not a politically defining moment of indigeneity - "to be indigenous is to participate as a liberal subject of political economy"-but is an instance of "distress sale" resorted to by both indigenous and nonindigenous poor. It is the lowest common denominator of economic survival, when all else has failed. Both the history of marginal populations in capitalism and the contemporary collapse of our global speculative economy are not-so-gentle reminders of the need to resist this logic of converting land into liquidity in which most populations-indigenous, peasant, U.S. middle class-have little chance to win the speculation race. Land with full liquidity is what after all has been 
the dominant thrust of "global history" and the site where microprocesses (agrarian/local) and macroprocesses (financial/global) of capitalism are most synchronized.

Rather than being deadlocked in land as "inalienable collective" versus " alienable private," it may be helpful to insist on 1 above and accept the extant and emerging regimes of indigenous land protection to be a turbulent site of both indigenous agency and shifting governmentalities. Indigenous land protection can be effective without the reified essentialisms of "collective ownership," as witnessed in the individual but largely inalienable indigenous tenures in India or Vietnam (n. 17). Taking these land regimes as significant but imperfect points of articulation of indigeneity, I think it is important to move away from the lowest common denominator of "distress sales" and think of more effective possibilities of stopping indebtedness and agrarian land alienation. First, it is clear that the severe crisis of marginal farms and indigenous landowners has generated some internal answers, however unsatisfactory. Indigeneity as deceptively sedentary (collective land ownership) is matched by an equally extensive history of migratory work. Here we must notice that such migration is rarely en masse and comes frequently from families with substantial and marginal land ownership. Migrant remittances are often used to make sure the family does not have to sell land in order to ensure basic survival or access to food, education, more competitive agriculture, ritual expenses, and so forth. This demands the privileging of the question of indigenous land/territorial control in the struggles to generate alternate indigenous economies, including ones directly entangled with capital. These may involve the seemingly mundane projects associated with sustainable agriculture to the more exotic ventures of indigenous capitalism involving forestry, niche farming, "ecotourism," and alternate energy. All of these have significant "histories" by now, and we need to examine them in detail to rekindle the debate on indigeneity, dispossession, and "going beyond the dam."

\section{Rusaslina Idrus}

Institute for Southeast Asian Studies, 30 Heng Mui Keng

Terrace, Pasir Panjang, 119614, Singapore (rusaslina.idrus@ gmail.com). 26 XI 09

Li convincingly argues that attempts to protect "indigenous" communities from the perceived threat of capitalism by limiting their form of tenure to collective landholdings does not necessarily represent the communities' desire, need, or true relationship to the land. This article extends Li's persuasive work in The Will to Improve, showing striking parallels between the roles of different forms of "governors," from colonial governments to present-day institutions and advocacy groups, in imposing their own values and assumptions about what is best for communities. Here I would like to raise two points for discussion-what Li refers to as "the micropro- cesses of dispossession" and the heterogeneity of individual and collective landholdings.

I agree with Li's assessment that the simplistic narrative that indigenous peoples are "victims of capitalist processes intruding from outside" obfuscates the internal microprocesses of dispossession. Here I would like to further emphasize that aside from "microcapitalism," it is important to pay attention to political and historical processes that contribute to the marginalization and dispossession of certain groups. For example, in Malaysia, Orang Asli are acknowledged as the aboriginal people of the land; however, Malays, who are the ruling majority, also claim to be indigenous. On the surface, the processes of dispossession faced by Orang Asli are driven by economic forces. In the country's drive to become a developed nation by the year 2020, Orang Asli are literally and figuratively in the way. However, as I illustrate in my research, Orang Asli's dispossession from their land is also the result of complex historical and political processes that positioned Malays as indigenous people with special privileges and Orang Asli as a marginalized group with limited rights (including land rights). During the colonial period, Malays were the "chosen" natives, while Orang Asli were considered primitives. This racial ideology carried forth into the present. Here, to understand dispossession one needs to examine the history and politics of native rights in the country.

Community members, as $\mathrm{Li}$ points out, have divergent views on the form of landholding that they should have. Some demand collective tenure, while others want individual land titles. Orang Asli groups mostly live on government land (either on aboriginal reserves or areas or on state land) where at best they are tenants-at-will, subject to being relocated or evicted (without compensation) to make way for "development" projects. Lack of tenure security is a common predicament for indigenous minority groups in Malaysia. For many, their main concern is getting legal protection over their land, whether in the form of communal or individual land titles or both. However, many also feel that some form of communal tenure is imperative to ensure the integrity of the community. Orang Asli leaders assert that without communal landholding, which they see as an integral part of their collective identity as aborigines, their community will eventually disappear, assimilated into the dominant Malay community.

The discussion in Li's paper focused mostly on two forms of property rights - collective versus individual landholding. As anthropologists have shown, there are diverse forms of property rights that are practiced by indigenous communities. A group may share certain parts of the forest while some areas are divided individually according to an internal system. A plot of land may belong to one family until allowed to fallow, then ownership may be transferred to the next person who works the land. While Li correctly points out the tendency for activists to "arborealize" communities while downplaying the fact the "forest dwellers" are also farmers, we must also not forget that in many cases, these farmers are also hunters, forest collectors, and swidden agriculturalists. It is not unusual 
(at least in Borneo and Malaysia) for indigenous farmers to have wet rice fields as well as swidden fields. The forest also serves as hunting ground and a source for food, medicine, and building materials. These activities require some form of communal landholding to work. While I thoroughly agree that we should be wary of the imposition of collective tenure and the kinds of romantic association that goes with it (e.g., cohesive community, one-with-nature, etc.), the alternative of individual titles may not be desired by the community either.

In Malaysia, the government's most recent proposal (in part, after finding themselves challenged in court by indigenous groups over customary land) was to allocate individual land titles to 30,000 Orang Asli households, with each household allocated 6.25 acres of land. Orang Asli advocates have pointed out the total land area proposed under this plan was actually $40 \%$ less than the total existing Orang Asli recognized areas (but for which Orang Asli do not have secure tenure). On top of that, the individual titles had an expiration datethey were 99-year leases. In this example, individual landholdings in the form that was proposed here do not offer the kind of tenure security that the community wants. This illustrates the heterogeneity of tenure systems and the need to unpack the specificity of each option for each distinct community.

\section{Pauline E. Peters}

Center for International Development, John F. Kennedy School of Government, Mailbox 37, 79 JFK Street, Cambridge, Massachusetts 02138, U.S.A. (pauline_peters@ harvard.edu). 16 XI 09

I follow Tania Li in her short foray into Africa with the same intention of "opening a line of comparative inquiry." Her Asian-focused canvas is large, so I will focus on the relevance of the "communal fix" to Africa (or to the parts of that large continent I know somewhat). There were indeed sufficient similarities in the mind-sets and practices of nineteenthcentury colonial officers (and missionaries) to create parallel communal tenure and customary law over highly variegated landholding practices across vast regions. But these constructions in colonial Africa were less the result of fear of the effects of capitalism on natives (that came somewhat later in terms of modernization and development rather than capitalism) than to a need for units of authority for what became known as "indirect rule." Those constructions—albeit modified, adapted, and transformed over time-continue to be implicated in land relations and land policies today. From their establishment, these constructions were politicized: chiefs, elders, and men used their chance to maneuver among themselves and vis à vis commoners, juniors, and women. Along with the colonial regulations on trade (most Africans were barred from more than petty trade, to the advantage of European settlers and/or imported middlemen such as east
Asians), residence, taxation, and so forth, they fed into longestablished and ongoing processes of socioeconomic differentiation. As in the Asian cases, colonialists were not all in agreement, but different opinions and research showing the effectiveness of African forms of agriculture and the individualized uses and rewards entailed in communal tenure were sidelined. The occasional voice positing the need for policy on titling was also ignored until the late 1940s and 1950s, when the postwar enthusiasm for a technical fix drove new development programs in many African territories. The era of grandiose projects was cut short for colonialists by the move to independence for African states. But such projects often reappeared in the new states, and despite many states taking over the colonial presumption as ultimate sovereign of land and multiple efforts at land-policy reform, customary tenure and law continued to hold in most rural areas because they provided a structure of authority useful for order and patronage from the top down. Customary tenure continues to be an inadequate gloss for what are various forms of holding and transfer, including sharecropping, rentals, and even sales, though its ideology-notions of land held in trust by traditional authorities on behalf of collectivities-continues to be invoked (Benjaminsen and Lund 2003; Chimhowu and Woodhouse 2006; Kuba and Lentz 2006; Lund 2008; Ubink and Amanor 2008).

The democratic moves to multiparty regimes over the past decade have increased the leverage for subnational authorities, especially chiefs, as they may provide voting blocs in return for patronage from politicians. One outcome is lobbying for their traditional role as trustees over customary land in the new wave of land-policy reforms (instigated largely by the World Bank). Another is intensified regionalist and ethnic rivalries, sometimes transmuted into civil unrest and wars. Centrally involved in these rivalries are land and its resources and authority over these and over people. A flood of research has documented intensified competition and conflict over land despite the fact that in most countries, the ratio of landlessness is very low by comparison with the Asian countries discussed by Li. The resulting divisions between and within lineages and ethnic and regional groups often take place in terms of relative belonging setting locals or autochthones against strangers or in-migrants (even after several generations of settlement). Here, the invocation in English and cognate languages of indigenous has a different resonance than that described by Li for most of the Asian cases (and for the very few in Africa, such as the Bushmen of southern Africa). Indigenous rights are not an issue in the sense now well known internationally. But relative indigeneity in the sense of prior occupation, often layered with ethnic identifications, plays an increasingly divisive role in land conflicts, again playing into wider forms of differentiation and class formation. Competition over landed resources is not merely a local issue; in many cases it involves international agents, such as companies and governments (in collaboration with members of African elites using the state as gatekeeper) greedy for the minerals, 
oil, and timber of Africa. Multidisciplinary research includes many interested in revealing the dispossessory effects of capitalism and of such new communal fixes as community-based conservation projects, but many are also concerned with the other side of those effects, namely, processes of accumulation (Cooper 2002; Reno 2001; Ribot 1999). Perhaps implicit in Li's analysis, the mutual relation between dispossession and accumulation at multiple levels needs emphasis. Finally, in African studies there is disagreement over the terms of debate: innovative work by Jane Guyer suggests parts of Africa are "commercial without being capitalist, even while [their] dynamics link into and confront the capitalist market" (Guyer 1997:184), and "neither class nor market analysis alone can do justice" (2004:69) to the situation, while some, like myself, feel the language of class formation allows-as it has done elsewhere-for the cultural specificities of engagement with commodification and capitalism.

\section{Nancy Postero}

Department of Anthropology, University of California, San Diego, La Jolla, California 92093-0532, U.S.A. (npostero@ ucsd.edu). 17 XI 09

Tania Li makes an important and counterintuitive argument about collective landholding among indigenous peoples. Whereas the predominant discourse holds that native peoples should work their lands collectively, as part of their "traditional" culture, Li argues that such collective landholding schemes are more often imposed from the outside by paternalistic colonial officials or experts assuming responsibility for deciding who should be exposed to the risks of the market. She amasses compelling evidence demonstrating that people pushed into such schemes rarely conform to experts' assumptions. Instead, caught in the "simple reproduction squeeze" of debt, taxes, and falling prices for their crops, they often sell their lands and fall into poverty, vexing officials charged with their protection.

Li's article is an important wake-up call to all those working with indigenous peoples; as anthropologists documenting their struggles or development workers trying to "improve" their situations. Pointing to dangers in the contemporary construction of indigenousness, Li convincingly argues that pushing indigenous peoples into collective enclaves does not address the larger structural issue: the continuing dispossessory effects of capitalism.

My experience in Bolivia supports her argument. During the height of the 1990s "neoliberal multiculturalism," when the rhetoric of both indigenous people and governmental officialdom promoted collective landholding as the ideal, I watched as the Guaraní people I worked with chose to sell their lands. These were migrants to the zone, people already subject to prior dispossessions in their "land of origin." In the late 1960s, they had gained land near the regional capital in an agrarian reform scheme, but it was unclear whether the title was held collectively. This ambiguous situation held for many years until the nearby city expanded and land values skyrocketed. Then a bitter conflict erupted between Guaraní "brothers." Many in the community relied on an "indigenous tradition" of collectivity, arguing that land was sacred and should not be considered a commodity. Others denied this, arguing that they had a right to sell their lands to fund businesses and educate their kids. Both sides turned to the historical record, but over the last hundred years, Guaranís have held their lands both ways, collectively and individually, depending on the circumstances. The economic realities of the boomtown soon trumped these historical-cultural debates. Much as Li describes, the Guaranís made rational calculations about land values and subsistence farming and sold their farm lands, saving only small plots for their houses. Whether we label this as compulsion or choice does not matter. The result was a new round of dispossession.

Li ends her article with a call to anthropologists to go beyond the naturalizing discourse of indigenous tradition to a careful tracing of the mechanisms of dispossession. I agree wholeheartedly. In the Bolivian case I describe, the result was not inevitable. There were years of contestation among community members, and many other options were proposed, including a collectively held land-development company. I documented many reasons why these did not turn out: infighting, lack of capital, lack of experience in the market, vulnerability to lawyers, etc. A major factor was a crisis in leadership, as local leaders were caught between their need to appear "traditional" and the pressures to capitalize on their only resource. But another reason these other options were not pursued is that those who wanted to sell their lands were labeled as corrupt or acting against the "Guaraní way." It seemed "unnatural" to see Indians selling their lands, even to me, an anthropologist who chose to work with urban indigenous groups precisely to get away from the stereotypes about Indians and their relation to sacred lands. What might have happened had indigenous people and their advocates had the discursive room to reimagine their resources and economic strategies outside the box of collective landholdings?

I am not advocating a grand sell-off of indigenous lands. In fact, one danger of Li's argument might be a "throwing the baby out with the bathwater" effect: recognizing that these schemes are often imposed might suggest they should be abandoned altogether. I do not read $\mathrm{Li}$ as suggesting this either, however, as her argument demonstrates that rural and native peoples have little relative power in the marketplace. In many places in Bolivia, the "defensive" solution of collective landholding has worked out very well, preserving land from predation by ranchers, colonists, railroads, and loggers. With sustainable management plans, Amazonian groups are harvesting lumber, chocolate, turtle eggs, and other products from their collectively held territories; running ecotourism lodges; and now thinking carefully about carbon swaps.

But these schemes do not work for everyone or in every place. In the community I described above, indigenous people 
found they could no longer sustain their rural livelihoods. Ten years later, the majority of the Guaraní still live there. They are still poor, but they have houses in a growing suburb with water, electricity, schools, a new health center, and regular bus service. They have lost the possibility of having an "indigenous community," and this continues to pain the older folk, but they have gained other forms of security that might mean more to their children in the coming years. Would they have been better off holding the land collectively? Li's article directs us to the critical question: who should decide?

\section{Elizabeth Rata}

Faculty of Education, University of Auckland, Private Bag 92 601, Symonds Street, Auckland 1035, New Zealand (e.rata@auckland.ac.nz).18 XI 09

Tania Li provides an important account of how indigeneity has functioned in colonial and contemporary periods as a mechanism of both dispossession and possession in the interest of capitalism's market forces. Using an impressive number of detailed examples from areas of Asia and Africa as well as brief references to New Zealand, the United States, and Mesoamerica, Li shows how the creation of indigeneity as a legal and administrative process works through communal ideologies to fix people to land. In this way, those who govern in capitalism's interests use processes of inclusion or exclusion of people to the land as a means to control the operation of the market.

A major insight in this remarkable article is its analysis of the extent of the contradictions involved in indigeneity. It discusses the widely accepted notion of indigeneity as a means by which those exposed to the land markets of capitalism resist dispossession. However, Li also includes an analysis of those wishing to enter the market on their own terms. These are people who seek to control the terms of the "dispossession" to become landowners rather than landless and powerless peasants or landed but equally powerless indigenes. The process may also enable emergent elites to secure possession in their own interests, leading to the dispossession of others within the group.

Indigeneity is shown to serve competing and contradictory claims. Its narrative as a defense against dispossession aligns with progressive politics. But the fixing of indigeneity in legal and administrative regimes, even in those cases where the process was designed to ensure stability and protect populations, produces unintended consequences that are not progressive. The permanent fixing of the collective is one. For $\mathrm{Li}$, "protection and incarceration are two sides of the same coin." It is an incarceration of permanence powerfully illustrated in Peter Sutton's recent analysis of the consequences of decades of protection for Australian Aborigines (Sutton 2009).

While the fixing of people to place and tradition as indigenous groups was an attempt, in both the eras Li discusses, to manage agrarian capitalism and the forces of dispossession, it is also used as a strategy of possession. She refers to the use of collective tenures over customary land that "colonial regimes invented" and the associated ideologies of community, tribe, and custom to "prevent, limit or otherwise manage dynamics of class formation" (Bernstein 2005:72). The quotation from Bernstein points to a major idea in her article that is somewhat undeveloped (a minor criticism given the comprehensive treatment of other ideas). However, her key idea, that indigeneity serves as an ideology in the management of capitalism, is powerfully argued.

I think she is correct to conceptualize indigeneity as "communal fixing," that is, as the ideological and practical management of people to land in response to capitalism's constantly changing requirements. This is an idea I wish to comment on further. In the contemporary period, the management strategies Li identifies in indigenous politics contribute to the shift by global capitalism away from progressive politics based in the democratic nation-state through processes generally referred to as globalization. The weakened nation-state, the increasing privatization of public resources, the decline of class consciousness, and the reemergence of traditionalist identities all serve the interests of global corporate capital. As communally defined groups use traditionalist ideologies to claim varying degrees of self-autonomy from the nation-state, the public space is diluted, the privatization of state-owned resources is accelerated, class interests are rejected for traditionalist ones, and emergent elites engage directly with global capitalism.

By analyzing indigeneity as one of the ideologies serving capitalism's management requirements, Tania Li has provided a powerful theoretical counter to the concept's reification. Such essentialism gives capitalist elites (those within indigeneity as well as external elites) an ideology that resists criticism because it appears progressive. Li's important contribution is that by showing how indigeneity operates as a strategy of both possession and dispossession, it becomes possible to analyze the effects of depoliticizing groups of people into fixed primordial categories placed permanently outside history. The effects on those locked into a timeless indigeneity are serious enough, as Peter Sutton's account of Australian Aborigines shows. However, Li's political-economy approach also suggests an important path forward for analyses of global capitalism's use of all forms of traditionalist ideologies. While her subject is how indigeneity is used as an ideology of management of people to land, in the possible transition to a postdemocratic world, other notions of the traditional based on religion and ethnicity are equally effective strategies in breaking down the progressive structures of the nation-state, the citizen, and the classed worker. One of several significant contributions of this article to the literature is that, by deessentializing indigeneity, Li has provided a theoretical analysis that is transferable to other postdemocratic traditionalist ideologies. 


\section{Irina Wenk}

Department of Social and Cultural Anthropology, University of Zurich, Andreasstrasse 15, 8050 Zurich, Switzerland (iwenk@access.uzh.ch). 1 XII 09

In this important article, Li touches on a sensitive subject that challenges activists, policy makers, scholars, and all those indigenous individuals who follow the scholarly literature, namely the issue of collective tenure regimes devised for specific groups of people as a measure to stem ongoing piecemeal dispossession. In my reading, the article makes the following noteworthy contributions. First, Li emphasizes the historical continuity that characterizes these well-intentioned attempts to govern rural land tenure by keeping certain populations' territories out of market reach. This historical perspective is significant because it uncovers the often-paternalistic ideological assumptions of many colonial "protectors" and alerts us to the existence of similar mentalities among today's developers.

Second, Li disputes the assumption that collective tenure is a natural feature of certain people's precapitalist economies that needs to be protected and argues against the wishful/ patronizing thinking of those who advocate collective tenure as a measure to prevent poor farmers from losing land and to keep tribal peoples where and how they are. Instead, she shows how collective tenure, and with it the very concept of indigeneity, must be understood as something that has developed out of earlier engagements with capitalism as defensive response to situations of increasing land scarcity. Protective property regimes are based on arbitrary notions of bounded communities and the alterity of the "indigenous," neglect historical and contemporary market involvement of these people, and fail to see that farmers often cannot escape exploitative relations.

While I essentially agree with Li's argument and consider her article a significant contribution at a time when a myriad of collective tenure regimes are being devised across the globe, data from research on "the management of dispossession" in Mindanao suggests that the relation between "top-down" impositions, such as the ones she describes, and "bottom-up" interactions with collective tenure deserves special attention.

The Philippines provide an exemplary case for highlighting colonial processes of differentiation along a lowland-highland divide, and the country's upland groups have been at the forefront to build up a national and Asia-wide consciousness of indigeneity. Hundreds of claims to collective title are currently pending with the responsible government agency, while some 42 titles have been issued to groups claiming indigenous status. Such claim making is based on the Indigenous Peoples' Rights Act of 1997. Hailed as a landmark piece of legislation (Rovillos and Morales 2002:11), the statute known as IPRA replicates many of the problematic assumptions Li points to in her paper. Called "anthropologically naïve" by IPRA's foremost critic, Gatmaytan (2007:21ff.), I reproduce these briefly.
First, indigenous communities are presented as economically self-sufficient and thus free of debt relations that oblige them to use land as collateral. Second, they are thought to have a collective interest in preserving their culture and remaining on their land-as if they were not fascinated by mainstream living and willing to sell land to avail themselves of things like karaoke machines. Third, the law assumes bounded, homogenous communities on likewise bounded territories. In reaction to the last, I show (Wenk 2005, 2010) that titling does not mean bounding ethnically homogeneous enclaves but distinctly heterogeneous spaces where settlers often constitute majorities. These assumptions have led to an almost exclusive focus on boundary-based policies, of which the IPRA is but the most recent example, and a neglect of ongoing exploitative interethnic relations (McDermott 2000).

However, in my experience, indigenous land claimants worry less about paternalistic impositions and erroneous assumptions than about how to make best use of the options available. In claiming collective titles, they seek to secure as large a territory as possible while, internally, recognizing each family's landholdings and clarifying ownership and usufruct rights where these remain ambiguous. Coevally, the tribal elite prohibits the sale and mortgaging of titled land to nonindigenous persons in accordance with what local people tellingly refer to as "our IPRA law." This restriction does not prevent people from engaging in the existing land market but channels land deals in a novel direction, a direction largely controlled by the titleholding group itself. Drawing on their newly acquired legal status as landowner, the titleholders actively shape the conditions under which outsiders may acquire and make use of their land and lease it to investors. With the income thus generated, the tribal elite hopes to lessen people's dependency on moneylenders and prevent further land loss.

Adding this perspective to Li's account, I would like to suggest the following. (1) Collective tenure regimes are to some degree imposed from "outside"/"above," but they also, once established, allow for novel options of market engagement. (2) Where protective tenure goes so far as to make indigenous collectivities owners, this new legal status enables people to actively shape the land market and set the conditions for land acquisition. (3) Li rightly points out that indigenous people engaged in capitalist ventures are not favorably seen by supporters of indigenous rights, many of whom dread the irresistible commodification of indigenous lands. The people among whom I did fieldwork took self-determination literally and tried a joint venture with an investor. This first attempt failed and left behind not just rotten bananas but broken dreams and confusion. Out of my own struggle to grapple with these events, and in what I understand to be a logical extension of Li's argument, I conclude that when we (anthropologists, experts, advocates) talk of self-determination, we must mean letting people make their own choices on how to deal with local specificities of capitalism. 


\section{Reply}

Land and liquidity are terms strikingly juxtaposed in Kaushik Ghosh's response. Even as images, these terms do not fit together. Land is solid. It is fixed in place. You cannot roll it up like a mat and take it away. It is invested with meanings, identities, and attachments, and it provides the basis for the muddy, grounded practices from which most of the world's population continues to derive an agrarian livelihood. Making it liquid, turning it into a fully fledged commodity that flows without boundaries, is a giant step. Hence, it is not surprising that there are efforts to keep it solid, to stop the flow, and to insist on the fixity of land and-by extension-of the people attached to land.

One goal of my article was to show that the parties promoting solid over liquid-countermovements, in Polanyi's terms-are polymorphous. They include the victims of capitalism who seek to protect themselves from its damaging effects; experts tasked with mitigating the chaos that follows in capitalism's wake; and critics of various persuasions who dispute the wisdom and necessity of profit as the organizing principle of social life. I did not dwell on Polanyi, however, because his vague term society does not give us sufficient analytical purchase to understand these social forces, when and how they emerge, or the contradictions among them (see Hart 2002). Expectations about countermovements block insights into processes of commodification that emerge substantially from below as farmers elect to turn solid land into a liquid asset in order to intensify their market engagement. Debt and distress sales are part of the story of dispossession, and I make them central to my argument; but there is also the element of desire, as Postero confirms, and the hope that risky behavior will pay off in improved livelihoods, access to education, and other elements of modern citizenship.

Taken together, the responses show that the dilemmas I highlighted in my article are far from resolved. In West Malaysia, the government is proposing to abrogate the existing (fragile, insecure) communal provisions for Orang Asli and replace them with 30,000 individual land titles. In India, Ghosh's conviction that full liquidity in land is a position from which poor people can only lose is set against Amita Baviskar's observation that 2.5 million adivasis have filed claims to obtain individual title to farmland formerly controlled by the Forest Department. These individual titles are, in principle, inalienable, but the long history of land concentration both among adivasis and between adivasis and others indicates that this barrier to liquidity is not likely to hold. Presumably, the adivasi farmers opting for individual title know the risks, as do the adivasi activists who helped to draft the new forest law. In this case, as in Malaysia, we need to know more about their debates and considerations. What are the current arguments for or against full liquidity in land, and what are the social forces supporting one position or the other?

While Malaysia and India seem to be moving away from collective land rights, the Philippines is actively recognizing, strengthening, and in some cases constituting them. As Irina Wenk observes, the new legal regime in the Philippines is an outcome of mobilizing from above and from below. It is hailed as a progressive model, but the proof is still to come. Some erstwhile proponents, including one she cites, have become vigorous critics, and we need to know why: what has gone wrong and what has gone right as this law has played out across varied "indigenous" terrain? Like all land law, it is a massive intervention with potentially far-reaching effects that shape not only the "room for maneuver" of differently situated subjects but also the broad processes and structures within which they will operate for generations to come.

I agree with Ghosh, Cramb, and Idrus that I have overstated the antinomies (collective vs. individual, alienable vs. inalienable) and given insufficient attention to the many hybrids that lie in between. I also agree with Ghosh that the urgent question concerns the degree of protection that different land regimes enable, a question best addressed empirically. What tenure regimes have we encountered that are effective in limiting processes of agrarian class formation and enabling smallscale farmers to prosper while holding securely onto their land? The most interesting examples I have come across are the hybrids described by Thomas Sikor in highland Vietnam, where some villagers, given the option of individualized tenure in the context of decollectivization after 1988, decided to retain the socialist-era principle of periodic redistribution of the established rice fields. Redistribution resonated, in some cases, with presocialist "indigenous" traditions, but in other cases villagers who had migrated to the highlands developed collectivist narratives out of their common experience of suffering as they struggled to establish themselves in a new locale. By distributing rice land according to household needs, villagers ensured everyone a subsistence "floor" while permitting private ownership and accumulation of newly developed rice land and the upland fields used for increasingly commercial agriculture. The two were intimately related: subsistence security enabled entrepreneurial risk taking. Overall, inequality increased, but so did the standard of living of all the households, including the poorest (Sikor 2004; Sikor and Pham 2005).

The Vietnam example is important because it is resolutely agrarian, and it demonstrates village agency to counteract agrarian class formation "from below" in a context where farmers encountered new opportunities to grow lucrative crops and accumulation was a real possibility. In contrast, most cases of the successful use of collective tenure to defend local land rights-including the examples cited by Posterorelate to nonagricultural land uses (forest, hunting, pasture) or focus on predation by outsiders (loggers, colonists, and builders of railroads). Or they relate to contexts where livelihoods are agrarian but accumulation is not happening. A 
striking example of the latter scenario is provided by William Roseberry (1976) in his discussion of the relative absence of agrarian class formation among Andean villagers, not because they were culturally opposed to it but because the exploitative relations set in place by landlords, merchants, and tax collectors were so severe that little or no surplus was retained within their communities. Without such a surplus, classes could not form.

Dayak farmers in Borneo, according to Rob Cramb, offer another example of a hybrid collective/individual tenure regime that has protected indigenous territories while also enabling commercial agriculture to flourish. The conditions in his case are quite different from those in highland Vietnam, where villagers addressed the need for subsistence security head-on and limited accumulation accordingly. Ratios between people and land in Borneo are still extremely low (16 people per $\mathrm{km}^{2}$ in 2005). Hence, it has been possible for individual farmers to take land out of the communally held forest and turn it into semiprivatized family-held swidden and then take land from the swidden pool and privatize it further by planting commercial crops such as rubber or oil palm without significantly diminishing the opportunity of other Dayak farmers in the same territory to pursue their own farming ventures.

Although as Cramb points out, Dayak groups have territorial boundaries that preceded market involvement, I do not equate territorial boundaries with provisions for collective land management. The main element that Dayak swiddeners manage is access to fallowed swidden land, which makes sense because this is land in which a preceding generation invested the initial labour of land clearing, and it is labor-not landthat is the scarce resource. But the conditions that require more active management (e.g., the need to allocate land among competing uses and competing users or to prevent land alienation, land accumulation, and landlessness) are only now beginning to arise, stimulated by the massive conversion of swidden land into oil palm. For the Dayak leader I quoted, it was the advent of land selling that convinced him that an invigorated sense of community and more (local, intracommunal) efforts to govern conduct were needed. This is the sequence that I placed at the core of my essay: provisions for active land management, especially collective provisions intended to restrict accumulation and protect a subsistence floor, do not precede exposure to market risk but follow from it. To test this argument in Borneo, we would need to learn more from Cramb about contemporary Dayak debates around land concentration and land alienation in the context of oil palm. If there is a countermovement against the individualization and commodification of land, who is part of that movement, and who is against it? What arguments do they make?

The points I want to restate, following Cramb's comment, are about specificity and sequencing, both of which I can approach by comparing the conditions in Borneo described by Cramb and others (Dove 1993) with those in my fieldwork sites on the neighboring Indonesian island of Sulawesi. On this island, the topography is more rugged, the population density in 2005 almost six times higher ( 92 per $\mathrm{km}^{2}$ in 2005), and the land frontier substantially closed. In one highland area that I have been tracking since 1990 ( $\mathrm{Li} 2002$ ), these conditions combined to produce a rapid and acute crisis of land availability when indigenous farmers took plots of land out of their collective swidden pool to plant the latest boom crop, cacao. There was a rapid process of agrarian class formation that created sharp divisions among neighbors and kin, as some accumulated land and capital while others slid into landlessness-a condition unthinkable when I first visited the area. For three reasons, the highlanders were completely unprepared to manage this transformation. First, they were less solidly formed as groups attached to territories than the more warlike Dayak described by Cramb. Their sense of boundaries, social and territorial, are rather loose, as their bilateral kin links spread throughout the hills, and they quickly assimilate outsiders to the category of kin, fictively at first and then through marriage. Second, contra the notion of a pan-archipelagic "right of avail" promoted by Van Vollenhoven and his followers, their concepts of community and customary law say very little about land and nothing at all about how to prevent its flow. Third, and most obviously, they were unprepared to counter the problem of agrarian class formation happening in their midst because they had not encountered anything like it before. It was these events, in tandem with my comparative reading, that caused me to question the received evolutionary narrative. What if the sequence is reversed, and communities mapped onto territories, with rules about collective and inalienable landholding, are not the "normal" state before agrarian capitalism but a formation that emerges in response to it? If it is a response, who makes this response, and what are the debates and considerations that inform them? And how many years, or generations, does it take for new concepts of collectivity pegged to land management to emerge?

From Pauline Peters' comment, I find it difficult to gauge whether my argument that collective landholding responds to the risk of piecemeal dispossession does or does not hold for the African situations familiar to her. She argues that indirect rule was and still is the main motivation for institutionalizing communal tenure regimes and that class differentiation has been strongly linked to identities (racialized, ethnic, place based) and to large-scale capital investments. I would like to know whether protective moves against agrarian class formation from below have also been part of the equation, under conditions when land becomes scarce. I quoted some sources that support this idea, but Peters does not comment on these, perhaps an indication that their role in the overall scheme of agrarian differentiation and land management has been small. Peters does seem to be sympathetic to the general project to which my paper contributes: the examination of the "cultural specificities of engagement with commodification and capitalism." 
Elizabeth Rata sees the emphasis on indigeneity in contemporary political and economic movements as problematic because it serves "capitalism's management requirements" while hiding behind a progressive mask, and it undermines the possibility of achieving evenhanded citizenship in the framework of the nation-state. I agree with Rata that these are real dangers, with the caveat entered by Baviskar: nation-states can also be racist and viciously dispossessory, electoral democracy and notions of the public good notwithstanding. But my analytical framework diverges from Rata's in an important respect. Rather than see "global capitalism" as a singular force with a unitary will and intention, I treat it as an assemblage that pulls together elements of diverse provenance (Li 2007a). Thus, indigeneity was not conjured unilaterally by "global capitalism" with its functional requirements any more than it was conjured from the top down by technologies for indirect rule. It has been woven from diverse threads that emerge from above and below in entanglements with capitalism that are rather more awkward than Rata suggests.

My argument, a counterintuitive one as Postero points out, is that indigeneity does not stand opposed to capitalism as a prior state on a linear, evolutionary trajectory or as a marker of ineffable otherness. Rather, it stands opposed to capitalism because it coemerged with it. Baviskar references coemergence when she observes that "dispossession and displacement have been a constitutive part of adivasi (tribal) subject formation in India from colonial times." I have extended scholarly and activist positions that recognize capitalism as a constitutive element in indigeneity by going "beyond the dam" and related episodes of large-scale displacement to highlight the role of piecemeal dispossession and class formation "from below." These have been endemic features of small-scale agrarian capitalism for more than two centuries and continue to jeopardize agrarian livelihoods despite multifarious efforts to counter them. These efforts will become stronger, I suggest, when the various mechanisms of dispossession are exposed and tackled head-on rather than being subsumed in optimistic scenarios that rule them out (i.e., by declaring land collective and/or inalienable), wish them away, or attribute them to oppressive processes that arrive from elsewhere. Anthropologists are well placed to examine how small-scale farmers access and use land, and also how they lose it. They can also track expert discourse about what is or is not good for farmers as they encounter (and counter, or help to reproduce) the refractory world of agrarian capitalism. Such analysis provides the groundwork that is necessary for constructive engagement.

-Tania Murray Li

\section{References Cited}

Akram-Lodhi, A. Haroon. 2005. Vietnam's agriculture: processes of rich peasant accumulation and mechanisms of social differentiation. Journal of Agrarian Change 5(1):73-116.

Akram-Lodhi, A. Haroon, and Cristobal Kay. 2009. The agrarian question: peasants and rural change. In Peasants and globalization: political economy, rural transformation, and the agrarian question. A. H. Akram-Lodhi and C. Kay, eds. Pp. 3-33. London: Routledge. Alexander, Jennifer, and Paul Alexander. 1982. Shared poverty as ideology: agrarian relationships in colonial Java. Man 17(4): 597-619.

- 1991. Protecting peasants from capitalism: the subordination of Javanese traders by the colonial state. Comparative Studies in Society in History 33(2):370-394.

AMAN, World Agroforestry Centre, and Forest Peoples Programme. 2003. In search of recognition. Bogor, Indonesia: AMAN.

Banerjee, Prathama. 2000. Debt, time and extravagance: money and the making of "primitives" in colonial Bengal. Indian Economic and Social History Review 37:423-445.

Barnes, R. H., Andrew Gray, and Benedict Kingsbury, eds. 1995. Indigenous peoples of Asia. Ann Arbor, MI: Association for Asian Studies.

Benjaminsen, Tor A., and Christian Lund, eds. 2003. Securing land rights in Africa. London: Cass. [PEP]

Bernstein, Henry. 1994. Agrarian classes in capitalist development. In Capitalism and development. L. Sklair, ed. Pp. 40-71. London: Routledge.

- 2004. "Changing before our very eyes": agrarian questions and the politics of land in capitalism today. Journal of Agrarian Change 4(1/2):190-225.

- 2005. Rural land and land conflicts in sub-Saharan Africa. In Reclaiming the land: the resurgence of rural movements in Africa, Asia and Latin America. S. Moyo and P. Yeros, eds. Pp. 67-101. London: Zed.

Berry, Sara. 1993. No condition is permanent: the social dynamics of agrarian change in sub-Saharan Africa. Madison: University of Wisconsin Press.

Beteille, Andre. 1998. The idea of indigenous people. Current Anthropology 39(2):187-192.

Bijoy, C. R. 2003. The adivasis of India: a history of discrimination, conflict, and resistance. PUCL Bulletin. http://www.pucl.org/ Topics/Dalit-tribal/2003/adivasi.htm.

Boomgaard, Peter. 1991. The Javanese village as a Cheshire Cat: the Java debate against a European and Latin American background. Journal of Peasant Studies 18(2):288-304.

Borras, Saturnino M., Jr. 2006. Redistributive land reform in "public" (forest) lands? lessons from the Philippines and their implications for land reform theory and practice. Progress in Development Studies 6(2):123-145.

Bowen, John. 2000. Should we have a universal concept of "indigenous peoples" rights? Anthropology Today 16(4):12-16.

Breman, Jan. 1980. The village on Java and the early-colonial state. Rotterdam: Comparative Asian Studies Program.

. 1983. Control of land and labour in colonial Java. Dordrecht: Foris.

. 2000. Labour and landlessness in South and South-east Asia. In Disappearing peasantries? D. Bryceson, ed. Pp. 231-246. London: Intermediate Technology.

Brenner, Robert. 1985. Agrarian class structure and economic development in pre-industrial Europe. In The Brenner debate: agrarian class structure and economic development in pre-industrial Europe. T. H. Alston and C. H. E. Philpin, eds. Pp. 10-63. Cambridge: Cambridge University Press.

Brosius, J. Peter. 1999. Analyses and interventions: anthropological engagements with environmentalism. Current Anthropology 40(3): 277-309.

Bryceson, Deborah Fahy. 2002. The scramble in Africa: reorienting rural livelihoods. World Development 30(5):725-739.

Burns, Peter. 1989. The myth of Adat. Journal of Legal Pluralism 28: $1-127$. 
KITLV.

Byres, Terence J. 2004. Neo-classical neo-populism 25 years on: déjà vu and déjà passé: towards a critique. Journal of Agrarian Change 4(1-2):17-44.

Chanock, Martin. 1991. Paradigms, policies and property: a review of the customary law of land tenure. In Law in colonial Africa. K. Mann and R. Roberts, eds. Pp. 61-84. London: Heinnemann.

Chayanov, A. V. 1986. The theory of peasant economy. Madison: University of Wisconsin Press.

Chimhowu, Admos, and Philip Woodhouse. 2006. Customary vs. private property rights? dynamics and trajectories of vernacular land markets in sub-Saharan Africa. Journal of Agrarian Change 6(3):346-371. [PEP]

Claassens, Aninka, and Ben Cousins, eds. 2008. Land, power and custom: controversies generated by South Africa's communal land rights act. Cape Town: University of Cape Town Press.

Cleary, M. C. 1992. Plantation agriculture and the formulation of native land rights in British North Borneo c. 1880-1930. Geographical Journal 158(2):170-181.

Colchester, Marcus. 1994. Sustaining the forests: the communitybased approach in south and south-east Asia. Development and Change 25:69-100.

- 2005. Dayak leaders' memories and dreams: report on a survey of oil palm plantations and indigenous peoples in West Kalimantan. Moreton-in-Marsh, UK: Forest Peoples Programme.

. N.d. Indigenous peoples and communal tenures in Asia. In FAO corporate document repository. http://www.fao.org/docrep/ 007/y5407t/y5407t07.htm (accessed April 15, 2010).

Colchester, Marcus, Norman Jiwan, Andiko, Martua Sirait, Asep Yunan Firdaus, A Surambo, and Herbert Pane. 2006. Promised land: palm oil and land acquisition in Indonesia: implications for local communities and indigenous peoples. Moreton-in-Marsh, UK: Forest People Programme and Perkumpulan Sawit Watch.

Colchester, Marcus, Martua Sirait, and Boedi Wijardjo. 2003. The application of FSC principles $2 \& 3$ in Indonesia: obstacles and possibilities, discussion document for multi-stakeholder dialogue, 21-23 January 2003. Jakarta, Indonesia: WALHI, AMAN, Rainforest Foundation.

Conklin, Beth, and Laura Graham. 1995. The shifting middle ground: Amazonian Indians and eco-politics. American Anthropologist 97(4):695-710.

Contreras-Hermosilla, Arnoldo, and Chip Fay. 2005. Strengthening forest management in Indonesia through land tenure reform: issues and framework for action. Bogor, Indonesia: Forest Trends/ World Agroforestry Centre.

Cooke, Fadzilah Majid. 2002. Vulnerability, control and oil palm in Sarawak: globalization and a new era? Development and Change 33(2):189-211.

Cooper, Frederick. 2002. Africa since 1940: the past of the present. Cambridge: Cambridge University Press. [PEP]

Corbridge, Stuart. 1988. The ideology of tribal economy and society: politics in Jharkhand, 1950-1980. Modern Asian Studies 22:1-42.

Cowen, Michael, and Robert Shenton. 1996. Doctrines of development. London: Routledge.

Cramb, Rob. 2007. Land and longhouse: agrarian transformation in the uplands of Sarawak. Copenhagen: NIAS.

Damodaran, Vinita. 2002. History, landscape, and indigeneity in Chotanagpur, 1850-1980. South Asia: Journal of South Asian Studies 25(2):77-110.

Davis, Mike. 2006. Planet of slums. London: Verso.

De Angelis, Massimo. 2001. Marx and primitive accumulation: the continuous character of capital's "enclosures." Commoner 2. http://www.thecommoner.org.

Deininger, Klaus, and Hans Binswanger. 2001. The evolution of the World Bank's land policy. In Access to land, rural poverty, and public action. A. de Janvry, J.-P. Platteau, G. Gordillo, and E. Sadoulet, ed. Pp. 406-440. Oxford: Oxford University Press.

De Koninck, Rodolphe, and Steve Dery. 1997. Agricultural expansion as a tool of population redistribution in Southeast Asia. Journal of Southeast Asian Studies 28(1):1-26.

de la Cadena, Marisol, and Orin Starn. 2007. Introduction. In Indigenous experience today. Pp. 1-30. Oxford: Berg.

Dewey, Clive. 1972. Images of the village community: a study in Anglo-Indian ideology. Modern Asian Studies 6:291-328.

Dirks, Nicholas B. 1992. From little king to landlord: colonial discourse and colonial rule. In Colonialism and culture. N. B. Dirks, ed. Pp. 175-208. Ann Arbor: University of Michigan Press.

Doolittle, Amity A. 2005. Property and politics in Sabah, Malaysia: native struggles over land rights. Seattle: University of Washington Press.

Dove, Michael R. 1993. Smallholder rubber and swidden agriculture in Borneo: a sustainable adaptation to the ecology and economy of the tropical rainforest. Economic Botany 47(2):136-147.

Down to Earth. 2003. Indigenous peoples force suspension of Jakarta aid meeting. Down to Earth 57. http://dte.gn.apc.org/57ind.htm (accessed May 19, 2005).

Eder, James, and Thomas McKenna. 2004. Minorities in the Philippines: ancestral lands and autonomy in theory and practice. In Civilizing the margins: Southeast Asian government policies for the development of minorities. C. Duncan, ed. Pp. 56-85. Ithaca, NY: Cornell University Press.

Eghenter, Cristina. 2000. What is Tana Ulen good for? considerations on indigenous forest management, conservation, and research in the interior of Indonesian Borneo. Human Ecology 28(3):331-357.

Ellen, Roy F. 1986. What Black Elk left unsaid: on the illusory images of green primitivism. Anthropology Today 2(6):8-12.

Ellsworth, Lynn. 2002. A place in the world: tenure security and community livelihoods, a literature review. Washington, DC/New York: Forest Trends/Ford Foundation.

Ellsworth, Lynn, and Andy White. 2004. Deeper roots: strengthening community tenure security and community livelihoods. New York: Ford Foundation.

Elson, Robert. 1994. Village Java under the cultivation system, 1830-1870, Asian Studies Association of Australia. Sydney: Allen \& Unwin.

-1997. The end of the peasantry in Southeast Asia: a social and economic history of peasant livelihood. London: Macmillan.

Fasseur, C. 1994. Cornerstone and stumbling block: racial classification and the late colonial state in Indonesia. In The late colonial state in Indonesia: political and economic foundations of the Netherlands Indies, 1880-1942. R. Cribb, ed. Pp. 31-56. Leiden: KITLV. Foucault, Michel. 1991. Governmentality. In The Foucault effect: studies in governmentality. G. Burchell, C. Gordon, and P. Miller, eds. Pp. 87-104. Chicago: University of Chicago Press.

Gatmaytan, Augusto B. 2007. Philippine indigenous peoples and the quest for autonomy: negotiated or compromised? In Negotiating autonomy: case studies on Philippine indigenous peoples' land rights. IWGIA Document 114. Augusto B. Gatmaytan, ed. Pp. 1-35. Quezon City, Philippines: Legal Rights and Natural Resources Center. [IW]

Geertz, Clifford. 1963. Agricultural involution: the processes of ecological change in Indonesia. Berkeley: University of California Press.

Ghosh, Kaushik. 2006. Between global flows and local dams: indigenousness, locality, and the transnational sphere in Jharkhand, India. Cultural Anthropology 21(4):501-534.

Glassman, Jim. 2006. Primitive accumulation, accumulation by dispossession, accumulation by "extra-economic" means. Progress in Human Geography 30(5):608-625.

Guyer, Jane I. 1997. An African niche economy: farming to feed Ibadan, 1968-88. Edinburgh: Edinburgh University Press for IAI. [PEP] 
2004. Marginal gains: monetary transactions in Atlantic Africa. Chicago: University of Chicago Press. [PEP]

Hale, Charles R. 2006. Activist research v. cultural critique: indigenous land rights and the contradictions of politically engaged anthropology. Cultural Anthropology 21(1):96-120.

Hall, D., P. Hirsch, and T. M. Li. Forthcoming. Powers of exclusion: land dynamics in rural Southeast Asia. Singapore: National University of Singapore Press.

Hart, Gillian. 2002. Developments after neoliberalism: culture, power, political economy. Progress in Human Geography 26(6):812-830. 2006. Denaturalizing dispossession: critical ethnography in the age of resurgent imperialism. Antipode 38(5):977-1004.

Hetherington, Kregg. 2008. Guerrilla auditors: transparency, democracy and rural politics in Paraguay. PhD dissertation, University of California, Davis.

2009. Privatizing the private in rural Paraguay: precarious lots and the materiality of rights. American Ethnologist 36(2): 224-241.

Hodgson, Dorothy L. 2002. Introduction: comparative perspectives on the indigenous rights movement in Africa and the Americas. American Anthropologist 104(4):1037-1049.

Hugenholtz, W. R. 1994. The land rent question and its solution 1850-1920. In The late colonial state in Indonesia: political and economic foundations of the Netherlands Indies, 1880-1942. R. Cribb, ed. Pp. 139-172. Leiden: KITLV.

Husken, Frans. 1989. Cycles of commercialization and accumulation in a central Javanese village. In Agrarian transformations: local processes and the state in Southeast Asia. G. Hart, A. Turton, and B. White, eds. Pp. 303-331. Berkeley: University of California Press.

Husken, Frans, and Benjamin White. 1989. Java: social differentiation, food production, and agrarian control. In Agrarian transformations: local processes and the state in Southeast Asia. G. Hart, A. Turton, and B. White, eds. Pp. 235-265. Berkeley: University of California Press.

Idrus, Rusaslina. 2008. The politics of inclusion: law, history and indigenous rights in Malaysia. PhD dissertation, Harvard University.

Igoe, Jim. 2006. Becoming indigenous peoples: difference, inequality, and the globalization of East African identity politics. African Affairs 105(419):1-22.

James, Deborah. 2006. The "tragedy of the private": owners, communities and the state in South Africa's land reform programme. In Changing properties of property. F. von Benda-Beckmann, K. von Benda-Beckmann, and M. Wiber, eds. Pp. 243-268. New York: Berghan.

James, Deborah, and Albert Schrauwers. 2003. An apartheid of souls: Dutch and Afrikaner colonialism and its aftermath in Indonesia and South Africa: an introduction. Itinerario 27(3/4):49-80.

Jorgensen, Bent. 2006. Development and "the other within": the culturalisation of the political economy of poverty in the northern uplands of Viet Nam. PhD dissertation, Peace and Development Research, Goteborg.

Kahn, Joel. 1993. Constituting the Minangkabau: peasants, culture and modernity in colonial Indonesia. Oxford: Berg.

Kanbur, Ravi. 2001. Economic policy, distribution and poverty: the nature of disagreements. World Development 29(6):1083-1094.

Karlsson, Bengt G. 2003. Anthropology and the "indigenous slot." Critique of Anthropology 23(4):403-423.

Kerkvliet, Benedict. 2005. The power of everyday politics: how Vietnamese peasants transformed national policy. Ithaca, NY: Cornell University Press.

Kratoska, Paul H. 1985. The peripatetic peasant and land tenure in British Malaya. Journal of Southeast Asian Studies 16(1):16-45.

Kuba, Richard, and Carola Lentz, eds. 2006. Land and the politics of belonging in West Africa. Leiden: Brill. [PEP]

Land Equity International. 2003. Comparative study of land admin- istration systems: critical issues and future challenges. Preliminary report prepared for the World Bank. Wollongong, Australia: Land Equity International.

La Via Campesina and FIAN International. 2006. Rights, resources and resistance. Paper presented at the Land, Poverty, Social Justice and Development conference, Institute of Social Studies, The Hague, January 9-14.

Lehman, F. K. L., Chit Hlaing. 2003. The relevance of the founders' cult for understanding the political systems of the peoples of northern Southeast Asia and its Chinese borderlands. In Founders' cults in Southeast Asia: ancestors, polity, and identity. N. Tannenbaum and C. A. Kammerer, eds. Pp. 15-39. New Haven, CT: Yale University Press.

Lev, Daniel S. 1985. Colonial law and the genesis of the Indonesian state. Indonesia 40:57-74.

Li, Tania Murray. 1999. Compromising power: development, culture and rule in Indonesia. Cultural Anthropology 14(3):1-28.

. 2000. Articulating indigenous identity in Indonesia: resource politics and the tribal slot. Comparative Studies in Society and History 42(1):149-179.

- 2001a. Masyarakat Adat, difference, and the limits of recognition in Indonesia's forest zone. Modern Asian Studies 35(3): 645-676.

$2001 b$. Relational histories and the production of difference on Sulawesi's upland frontier. Journal of Asian Studies 60(1):41-66.

. 2002. Local histories, global markets: cocoa and class in upland Sulawesi. Development and Change 33(3):415-437.

- 2007a. Practices of assemblage and community forest management. Economy and Society 36(2):264-294.

- 2007b. The will to improve: governmentality, development, and the practice of politics. Durham, NC: Duke University Press.

Lund, Christian. 2008. Local politics and the dynamics of property in Africa. Cambridge: Cambridge University Press. [PEP]

Lynch, Owen, and Emily Harwell. 2002. Whose natural resources? whose common good? towards a new paradigm of environmental justice and the national interest in Indonesia. Jakarta, Indonesia: Lembaga Studi dan Advokasi Masyarakat (ELSAM).

Lynch, Owen J., and Kirk Talbott. 1995. Balancing acts: communitybased forest management and national law in Asia and the Pacific. Washington, DC: World Resources Institute.

Mamdani, Mahmood. 1996. Citizen and subject: contemporary Africa and the legacy of late colonialism. Princeton, NJ: Princeton University Press.

McDermott, Melanie Hughes. 2000. Boundaries and pathways: indigenous identity, ancestral domain, and forest use in $\mathrm{Pa}$ lawan, the Philippines. PhD dissertation, University of California, Berkeley. [IW]

Mitchell, Timothy. 2002. Rule of experts: Egypt, technopolitics, modernity. Berkeley: University of California Press.

Moore, Donald. 2005. Suffering for territory: race, place, and power in Zimbabwe. Durham, NC: Duke University Press.

Moyo, Sam, and Paris Yeros. 2005. The resurgence of rural movements under neoliberalism. In Reclaiming the land: the resurgence of rural movements in Africa, Asia and Latin America. S. Moyo and P. Yeros, eds. Pp. 8-64. London: Zed.

Netting, Robert M. 1993. Smallholders, householders: farm families and the ecology of intensive, sustainable agriculture. Stanford, CA: Stanford University Press.

Pels, Peter. 1999. The rise and fall of the Indian aborigines. In Colonial subjects: essays on the practical history of anthropology. P. Pels and O. Salemink, eds. Pp. 82-116. Ann Arbor: University of Michigan Press.

Peluso, Nancy Lee, and Peter Vandergeest. 2001. Genealogies of the political forest and customary rights in Indonesia, Malaysia, and Thailand. Journal of Asian Studies 60(3):761-812.

Perelman, Michael. 2000. The invention of capitalism: classical political 
economy and the secret history of primitive accumulation. Durham, NC: Duke University Press.

Peters, Pauline. 2004. Inequality and social conflict over land in Africa. Journal of Agrarian Change 4(3):269-314.

Pincus, Jonathan. 1996. Class power and agrarian change: land and labour in rural West Java. London: Macmillan.

Polanyi, Karl. 1944. The great transformation. New York: Farrar \& Rinehart.

Postero, Nancy. 2006. Now we are citizens: indigenous politics in postmulticultural Bolivia. Stanford, CA: Stanford University Press.

Povinelli, Elizabeth. 1999. Settler modernity and the quest for an indigenous tradition. Public Culture 11(1):19-48.

Ramos, Alcida Rita. 2000. Pulp fictions of indigenism. In Race, nature and the politics of difference. D. Moore, A. Pandian, and J. Kosek, eds. Pp. 346-379. Durham, NC: Duke University Press.

Rata, Elizabeth. 2002. The transformation of indigeneity. Fernand Braudel Center Review 25(2):173-195.

. 2003. Late capitalism and ethnic revivalism. Anthropological Theory 3(1):43-63.

Reno, William. 2001. How sovereignty matters: international markets and the political economy of local politics in weak states. In Intervention and transnationalism in Africa: global-local networks of power. Thomas Callaghy, Ronald Kassimir, and Robert Latham, eds. Pp. 197-215. Cambridge: Cambridge University Press. [PEP]

RETORT (Iain A. Boal, T. J. Clark, Joseph Matthews, and Michael Watts). 2005. Afflicted powers: capital and spectacle in a new age of war. London: Verso.

Ribot, Jesse. 1999. Decentralization and participation in Sahelian forestry: legal instruments of central political-administrative control. Africa 69(1):23-64. [PEP]

Richards, A. J. N. 1961. Sarawak land law and Adat. Kuching, East Malaysia: Government Printer. [RC]

Rights and Resources Initiative. 2005. A new global initiative advancing forest tenure, policy and market reforms to reduce poverty, strengthen forest governance, conserve and restore forest ecosystems and achieve sustainable forest-based economic growth. http://www.forest-trends.org/documents/files/doc_106.pdf (accessed April 16, 2010).

Roseberry, William. 1976. Rent, differentiation, and the development of capitalism among peasants. American Anthropologist 78(1): 45-58.

Roseberry, William, and Jay O’Brien. 1991. Introduction. In Golden ages, dark ages. W. Roseberry and J. O’Brien, eds. Pp. 1-18. Berkeley: University of California Press.

Rosset, Peter M. 2006. Agrarian reform and food sovereignty: inseparable parts of an alternative framework. Paper presented at the Land, Poverty, Social Justice and Development conference, Institute of Social Studies, The Hague, January 9-14.

Rovillos, Raymundo D., and Daisy N. Morales. 2002. Indigenous peoples/ethnic minorities and poverty reduction, Philippines. Manila, Philippines: Environment and Social Safeguard Division, Regional and Sustainable Development Department, Asian Development Bank. [IW]

Salemink, Oscar. 1999. Ethnography as martial art: ethnicizing Vietnam's Montagnards, 1930-1954. In Colonial subjects: essays on the practical history of anthropology. P. Pels and O. Salemink, eds. Pp. 282-325. Ann Arbor: University of Michigan Press.

Sandall, Roger. 2001. The culture cult: designer tribalism and other essays. Boulder, CO: Westview.

Schrieke, B. 1955. Indonesian sociological studies. The Hague: van Hoeve.

Scott, James C. 1985. Weapons of the weak: everyday forms of peasant resistance. New Haven, CT: Yale University Press.

Scott, William Henry. 1985. Cracks in the parchment curtain and other essays in Philippine history. Quezon City, Philippines: New Day.

Sikor, Thomas. 2001. Agrarian differentiation in post-socialist soci- eties: evidence from three upland villages in north-western Vietnam. Development and Change 32(4):923-949.

- 2004. Conflicting concepts: contested land relations in north-western Vietnam. Conservation and Society 2(1):75-96.

Sikor, Thomas, and Thi Tuong Vi Pham. 2005. The dynamics of commoditization in a Vietnamese uplands village, 1980-2000. Journal of Agrarian Change 5(3):405-428.

Skaria, Ajay. 1997. Shades of wildness: tribe, caste, and gender in western India. Journal of Asian Studies 56(3):726-745.

Sutton, Peter. 2009. Politics of suffering. Carlton, Victoria: University of Melbourne Press. [ER]

Sylvain, Renee. 2002. Land, water, and truth: San identity and global indigenism. American Anthropologist 104(4):1074-1085.

Ter Haar, B. 1948. Adat law in Indonesia. New York: Institute of Pacific Relations. [RC]

Tiffen, Mary. 1996. Blind spots in the study of the "resource-poor" farmer. In The lie of the land: challenging received wisdom on the African environment. M. Leach and R. Mearns, eds. Pp. 168-185. London: International African Institute.

Tsing, Anna Lowenhaupt. 2003. Agrarian allegory and global futures. In Nature in the global south: environmental projects in south and Southeast Asia. P. Greenough and A. L. Tsing, eds. Pp. 124-169. Durham, NC: Duke University Press.

Ubink, Janine M., and Kojo S. Amanor, eds. 2008. Contesting land and custom in Ghana: state, chief and citizen. Leiden: Leiden University Press. [PEP]

United Nations. 2007. United Nations declaration on the rights of indigenous peoples. Geneva, Switzerland: OHCHR.

Upadhyay, Videh. 2003. Their lands and our laws. http://www indiatogether.org/2003/mar/vu-triballands.htm (accessed April 16, 2010).

Vandergeest, Peter. 2003. Racialization and citizenship in Thai forest politics. Society and Natural Resources 16:19-37.

von Benda-Beckmann, Keebet, and Franz von Benda-Beckmann. 1985. Transformation and change in Minangkabau. In Change and continuity in Minangkabau: local, regional, and historical perspectives on West Sumatra. L. L. Thomas and F. von Benda-Beckmann, eds. Pp. 235-278. Athens: Ohio University Center for International Studies, Center for Southeast Asian Studies.

Walker, Andrew. 2001. The "Karen consensus": ethnic politics and resource use legitimacy in northern Thailand. Asian Ethnicity 2(2): $145-162$.

2004. Seeing farmers for the trees: community forestry and the arborealisation of agriculture in northern Thailand. Asia Pacific Viewpoint 45(3):311-324.

Warren, Kay B. 1998. Indigenous movements and their critics: pan-Maya activism in Guatemala. Princeton, NJ: Princeton University Press.

Watts, Michael. 1994. Development II: the privatization of everything? Progress in Human Geography 18(3):371-384.

1999. Collective wish images: geographical imaginaries and the crisis of national development. In Human geography today. D. Massey, J. Allen, and P. Sarre, eds. Cambridge: Polity.

Webster, Steven. 1998. Maori Hapu as a whole way of struggle: 1840s-50s before the land wars. Oceania 69(1):4-35.

Wenk, Irina. 2005. Bounded spaces of coexistence: land titling and settlers on indigenous domains in Mindanao, the Philippines. Tsantsa 10:181-185. [IW]

. 2010. Land titling in perspective: indigenous-settler relations and territorialization on a southern Philippine frontier. In Colonization and conflict: a comparative study of contemporary settlement frontiers in South and Southeast Asia. Daniel Geiger, ed. Munster: LIT. Forthcoming. [IW]

Wertheim, W. F. 1961. Introduction. In Indonesian economics: the concept of dualism in theory and policy. W. F. Wertheim, ed. Pp. 3-64. The Hague: van Hoeve.

White, Benjamin. 1983. "Agricultural involution" and its critics: 
twenty years after. Bulletin of Concerned Asian Scholars 15(2): $18-31$.

1989. Problems in the empirical analysis of agrarian differentiation. In Agrarian transformations: local processes and the state in Southeast Asia. G. Hart, A. Turton, and B. White, eds. Pp. 15-30. Berkeley: University of California Press.

White, Benjamin, and Gunawan Wiradi. 1989. Agrarian and nonagrarian bases of inequality in nine Javanese villages. In Agrarian transformations: local processes and the state in Southeast Asia. G. Hart, A. Turton, and B. White, eds. Pp. 266-302. Berkeley: University of California Press.

Wolf, Eric. 1957. Closed corporate peasant communities in Meso- america and central Java. Southwestern Journal of Anthropology 13(1):1-18.

Wood, Ellen Meiksins. 2002. The origin of capitalism: a longer view. London: Verso.

World Bank. 1990. World development report 1990: Poverty. Washington, DC: World Bank.

2004. Land management and policy development project: appraisal document. Jakarta, Indonesia: World Bank.

. 2005. Operational policies: indigenous peoples (OP4.10). Washington, DC: World Bank.

2008. World development report: agriculture for development. Washington, DC: World Bank. 